\title{
Basal metabolic rate studies in humans: measurement and development of new equations
}

\author{
CJK Henry* \\ School of Biological and Molecular Sciences, Oxford Brookes University, Gipsy Lane Campus, Oxford OX3 OBP, UK
}

\begin{abstract}
Objective: To facilitate the Food and Agriculture Organization/World Health Organization/United Nations University Joint (FAO/WHO/UNU) Expert Consultation on Energy and Protein Requirements which met in Rome in 1981, Schofield et al. reviewed the literature and produced predictive equations for both sexes for the following ages: $0-3,3-10,10-18,18-30,30-60$ and $>60$ years. These formed the basis for the equations used in $1985 \mathrm{FAO} / \mathrm{WHO} / \mathrm{UNU}$ document, Energy and Protein Requirements.

While Schofield's analysis has served a significant role in re-establishing the importance of using basal metabolic rate (BMR) to predict human energy requirements, recent workers have subsequently queried the universal validity and application of these equations. A survey of the most recent studies (1980-2000) in $\mathrm{BMR}$ suggests that in most cases the current $\mathrm{FAO} / \mathrm{WHO} / \mathrm{UNU}$ predictive equations overestimate BMR in many communities. The FAO/WHO/UNU equations to predict BMR were developed using a database that contained a disproportionate number 3388 out of $7173(47 \%)$ - of Italian subjects. The Schofield database contained relatively few subjects from the tropical region.

The objective here is to review the historical development in the measurement and application of BMR and to critically review the Schofield et al. BMR database presenting a series of new equations to predict BMR.

Design: This division, while arbitrary, will enable readers who wish to omit the historical review of BMR to concentrate on the evolution of the new BMR equations. Setting: BMR data collected from published and measured values.

Subjects: A series of new equations (Oxford equations) have been developed using a data set of $10552 \mathrm{BMR}$ values that (1) excluded all the Italian subjects and (2) included a much larger number (4018) of people from the tropics.

Results: In general, the Oxford equations tend to produce lower BMR values than the current FAO/WHO/UNU equations in 18-30 and 30-60 year old males and in all females over 18 years of age.

Conclusions: This is an opportune moment to re-examine the role and place of BMR measurements in estimating total energy requirements today. The Oxford equations' future use and application will surely depend on their ability to predict more accurately the BMR in contemporary populations.
\end{abstract}

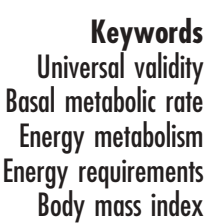

\section{Introduction}

Since the last Food and Agriculture Organization/World Health Organization/United Nations University (FAO/WHO/UNU) Expert Committee on Energy and Protein Requirements met in 1981, a considerable amount of work has been reported on the use and validity of the $\mathrm{FAO} / \mathrm{WHO} / \mathrm{UNU}^{1}$ equations to predict basal metabolic rate (BMR). This paper is divided into two parts - one will review the historical development in the measurement and application of BMR; and the second will critically review the Schofield BMR database and then present a series of new equations (Oxford equations) to predict BMR.
This division, while arbitrary, will enable readers who wish to omit the historical review of BMR to concentrate on the evolution of the new BMR equations.

Work concerning energy metabolism may be traced back to 1783 and the classical experiments of Lavoisier and Laplace. The principles of calorimetry laid down by these founding fathers over 200 years ago are still valid today. The development and subsequent apparatus used to measure respiratory exchange were based on the principles of calorimetry. The term 'basal' was used to distinguish between the energy expended while performing physical activity and being at rest. BMR represents the integration of minimal activity of all the tissues in the body 
under steady state conditions. It is usually expressed as heat production or oxygen consumption per unit body size. A more succinct definition of BMR was presented by Mitchell ${ }^{2}$ who said, 'Basal metabolism of an animal is the minimal rate of energy expenditure compatible with life'. In order to begin our analysis, it is appropriate to briefly review the historical developments in the study of BMR. This approach will enable us to appreciate the primary purpose of the early measures of BMR and how its application has evolved with time.

BMR is the daily rate of energy metabolism an individual needs to sustain in order to preserve the integrity of vital functions. It must be measured under conditions, which, as far as possible, avoid the influence of the external environment, for example heat, or cold, physical movement and the effects of food or drugs. If these conditions are observed, the result of the measurement is considered to represent the physiological and biochemical integrity of the individual concerned. In normal free-living persons, the amount of energy provided by their diet must cover the demands of basal metabolism plus additional amounts needed for the physical activity associated with essential bodily needs, and also those imposed by the physical work involved in occupation, in engaging in social exchanges and in leisure activities.

\section{Historical background: origins of the term 'basal metabolism'}

Magnus-Levy coined the term Grundumsatz or 'basal metabolism' in 1899. This term was of great value to the early investigators, as it emphasised the need to conduct the experiments under strictly standardised conditions. These included the following: (1) absence of gross muscular activity; (2) post-absorptive state; (3) minimal emotional disturbance; (4) wakefulness; (5) normal nutritive condition; (6) absence of disease or infection; and (7) thermo-neutral environment. In practice, however, it was impossible to impose all of the above conditions. For example, many of the early studies in humans reported by DuBois, Lusk and Rubner during the years 1900-1920 did not strictly meet the requirement of a thermoneutral environment, leading to a slightly elevated BMR. Moreover, many of the values reported by Aub and DuBois ${ }^{3,4}$ were obtained in anxious, untrained subjects. For this reason, the Aub-DuBois standards tended to be higher than other BMR standards.

The term 'basal metabolism' is often misunderstood to imply the lowest level of energy expenditure, which it clearly is not. During sleep and in conditions of undernutrition, metabolism may be lower than that observed under basal conditions. To avoid this confusion, Krogh coined the term 'standard metabolism'. In order to secure comparable results, the imposition of strict conditions for the measurement of BMR is essential.

\section{Conditions to be met while measuring BMR}

The concept of basal metabolism arose from the need to standardise measurements so that accurate comparisons could be made between individuals. This is achieved by measuring a minimum rate of heat production free of the effects of any consumption of food and 'extreme' physical environments ${ }^{6}$.

All BMR measurements must therefore meet the following conditions:

1. The subject should be completely rested, both before and during the measurements. They should be lying down and fully awake.

2. The subjects should be fasted for at least 10-12 hours before the measurements are taken.

3. The environment in which the measurements are taken should be thermo-neutral $\left(22-26^{\circ} \mathrm{C}\right)$ so that there is no thermoregulatory effect on heat production.

4. The subject should be free from emotional stress and familiar with the apparatus used.

\section{Ambient temperature during BMR measurements}

The ambient temperature at which energy expenditure is at a minimum was termed the 'critical temperature' by Rubner at the turn of the 20th century. The more commonly used term was 'zone of thermal neutrality'. This was defined as the ambient temperature above or below which resting metabolism of subjects begins to rise. The lowest ambient temperature at which an organism can maintain 'resting' or basal metabolic rate (without an increase in energy expenditure) is called the lower critical temperature. Work carried out on humans suggests the lower critical temperature to be between 22 and $27^{\circ} \mathrm{C}^{7,8}$. Numerous published works on BMR were conducted at temperatures as low as $9-15^{\circ} \mathrm{C}^{9}$. Indeed many of the early studies paid little attention to maintaining the subjects at thermoneutrality.

\section{Clinical and physiological standards}

During the early studies on BMR, there were two schools of thought on how BMR values should be represented. One group, called the 'clinical standard', assembled data on first tests on supposedly 'normal' subjects. As is now well known, first tests are usually higher in untrained subjects. Therefore, these values and standards led to values that were usually higher than those of the 'physiological standards'. On the basis of extensive review and observations of BMR values at that time, Roth and Buckingham ${ }^{10}$ made the point succinctly as follows, "more than one authority has stated on the basis of extensive travel and observation, that as many as $70 \%$ of the basal metabolism reports made today by the average operator may not be worth the paper on which they are written'. 


\section{Early use of BMR measurements}

BMR measurement in humans attracted considerable interest during the early part of the 20th century. They were primarily used for the diagnosis of hypo- and hyperthyroidism. BMR tests marked a new era in clinical medicine. It is interesting to note that until the mid-1950s the only reliable measure to diagnose thyroid dysfunction was to determine a subject's BMR. The study of basal metabolism represents an example of the early collaboration between physiologists and clinicians. BMR measurements were routinely made during clinical examinations and were believed to be instrumental in the diagnosis of thyroid disease, diabetes and leukaemia ${ }^{11}$.

\section{Use of BMR to predict energy requirements}

While BMR measurements were used in clinical diagnosis during the early part of the 20th century, the first comprehensive study to use BMR as the basis to estimate human energy requirements and hence food requirements was described by Bedale ${ }^{12}$. She studied a group of 45 boys and 55 girls aged 7-18 years. This was a significant departure from previous work as the early work on BMR was primarily intended to serve as metabolic reference values in clinical nutrition, notably in the diagnosis of hypo- and hyperthyroidism. It is, therefore, of interest to note that the $1985 \mathrm{FAO} / \mathrm{WHO} / \mathrm{UNU}^{1}$ approach to the estimation of energy requirements is a refinement of the method first described by Bedale ${ }^{12}$.

\section{FAO studies on calorie requirements}

The FAO nutrition studies No. $15^{13}$ published in 1957 , entitled Calorie Requirements, represented a landmark both in approach and analysis. Many of the previous reports on energy requirements proposed by Voit in 1890 , Atwater in 1895, Lusk in 1918 and the NRC (USA) published in 1943 and revised in $1953^{13}$, were based on food intake. The FAO ${ }^{13}$ publication proposed for the first time the use of energy expenditure to calculate energy requirements.

Two simplified empirical equations to predict energy requirements were presented:

Males: $\mathrm{E}=152 \mathrm{~W}^{0.73}$

Females: $\quad \mathrm{E}=123.47 \mathrm{~W}^{0.75}$

This was further simplified to:

Males: $\quad \mathrm{E}=815+36.6 \mathrm{~W}$

Females: $\quad \mathrm{E}=580+31.1 \mathrm{~W}$

where, E represents total energy requirements $\left(\mathrm{kcal} \mathrm{day}^{-1}\right.$ ) and $\mathrm{W}$ represents weight.

These simple linear equations to predict total energy requirements bear close resemblance to the linear equations used to predict BMR today. It is instructive to record that the concept of using energy expenditure to estimate energy requirements historically originated from the 1957 report of the $\mathrm{FAO}^{13}$.

\section{Current views on the use and application of BMR}

The resurgence of interest in BMR can be directly ascribed to a confluence of factors, notably two events. Firstly, a desire to understand the biology and aetiology of obesity and, secondly, the publication of the FAO/WHO/UNU document Energy and Protein Requirements in 1985 that proposed, for the first time, the use of energy expenditure (hence BMR) rather than food intake to calculate energy requirements. This new approach to estimate energy requirements emphasised the need to estimate accurately BMR in populations living under various climatic and environmental conditions. Under- or overestimation of BMR would severely affect the overall estimation of energy requirements.

If BMR measurements are to be used in estimating energy requirements, it is important to have some details on the apparatus used and the techniques adopted by various investigators during the past $80-90$ years. The following section will, therefore, review the methods and apparatus used to measure BMR between 1900 and 2000.

\section{Description of methodology: development of apparatus to measure BMR}

With the growing importance of determining BMR in the diagnosis and treatment of endocrine disorders (notably thyroid disorders), the demand and use of calorimetry rapidly expanded between 1910 and 1950. It was customary to use indirect calorimetry to measure BMR. The methods available to measure BMR may be divided into two types: closed and open circuit methods. In the closed circuit methods, the $\mathrm{CO}_{2}$ produced is absorbed within the system. Oxygen is added to maintain the volume of the gas constant. Benedict in 1918 initially devised a method where the amount of $\mathrm{CO}_{2}$ absorbed by soda-lime was carefully replaced by $\mathrm{O}_{2}$ which could be measured. Later, Krogh ${ }^{5}$ and Roth $^{14}$ developed an instrument that measured $\mathrm{O}_{2}$ consumption from the reduction in the volume of the gas by using a spirometer.

An interesting feature related to the pioneering studies on BMR was that, until 1919, calorimetry was confined to experimental laboratories under the control of highly trained scientists and technicians. With the advent of the Benedict-Roth spirometer (in the 1920s), which was a simple, portable calorimeter, the use and application spread widely. While this portable calorimeter was encouraged by some ${ }^{15}$, others were more critical. Roth and Buckingham ${ }^{10}$ commented 'many of these technicians educated overnight merely to man the machine, lacked training and experience necessary to face the multiplicity of problems to be otherwise encountered...Their work 
and reports were generally unquestioned because there were few capable of checking and passing judgement'. While it is impossible to gauge the impact such practices had on BMR measurements at that time, it nevertheless reinforces the need to examine more carefully and critically the methods used to estimate BMR during the early days of BMR collection. It is important to recognise that closed circuit was the more widely used method to measure BMR in the early days of its study.

The most commonly used closed circuit apparatus to measure BMR during the period 1910-1950 were the following:

1. Krogh spirometer

2. Benedict spirometer (universal apparatus)

3. Benedict-Roth spirometer

4. Knipping apparatus

5. Fleish metabometer-metabograph

The major drawback of the closed circuit method was that the absorption of $\mathrm{CO}_{2}$ did not allow the value of RQ to be calculated. As a rule, a value of 0.82-0.85 was assumed, leading to an error of up to $\pm 6 \%$ since the food undergoing oxidation had not been defined ${ }^{16}$.

\section{Problems related to the use of closed circuit apparatus}

The accurate determination of BMR requires firstly, that the subject be in the basal resting state (for either open or closed circuit calorimetry) and secondly for the rate of $\mathrm{O}_{2}$ consumption to be measured accurately. In closed circuit tests, the subject rebreathes from a spirometer that contains a $\mathrm{CO}_{2}$ absorber. It also contains $\mathrm{O}_{2}$ at a partial pressure much greater than the atmosphere. The period of rebreathing is usually $5-10$ minutes as subjects become uneasy if prolonged. The rate of $\mathrm{O}_{2}$ consumption in the subject is calculated from the average rate of decrease in volume from the spirometer. Numerous difficulties in obtaining accurate values using the spirometer have been reported. These include (1) completeness of $\mathrm{CO}_{2}$ absorbed, (2) volumetric calibration, and (3) Kymographic accuracy. Both $\mathrm{Krogh}^{5,17}$ and Benedict ${ }^{18}$ commented on the importance of the lung volume remaining effectively a constant at the beginning and end of the experimental period. If not, the changes in spirometer volume will represent not only the changes in $\mathrm{O}_{2}$ consumption but also changes in lung volume.

In a series of studies comparing the closed to the open circuit method to estimate BMR, Lewis et al. ${ }^{19-21}$ reported that the closed circuit overestimated BMR in 12 out of 25 adults and showed no difference in BMR measurements in the other subjects. Willard and Wolf ${ }^{22}$ reported another source of error with closed circuit calorimetry. This involved changes in chest volume during respiration. Changes in the expiratory position of the chest occurring during the experimentation had a marked effect on the slope of the tracing. Thus, a change in chest volume by its impact on the slope of the spirogram may lead to a falsely high apparent metabolic rate. A further reason for the elevated BMR values reported in the early literature was due to the usual practice at that time to record values from the first test. An additional source of error relates to the sample collection of $\mathrm{O}_{2}$ for a very short period of time (5-10 minutes). If hyperventilation had occurred (which is quite common in untrained subjects) an overestimation of energy expenditure would occur ${ }^{16}$. Moreover, these early studies did not maintain standard BMR conditions prior to testing. It must be remembered that the early BMR studies were used for clinical diagnostic purposes and not for any other metabolic usage.

BMR measurements using open circuit calorimetry show little difference due to type of equipment used ${ }^{23-26}$ using a range of methods, notably Douglas Bag, Oxylog, HB metabolator, ventilated hood, canopy and whole body calorimeter, showed marginal difference in BMR between methods used (see Table 1).

In contrast to the numerous studies comparing different methods of measuring BMR using open circuit calorimetry, few studies have compared closed circuit with open circuit calorimetry. Such comparisons as there are suggest that closed circuit calorimetry usually overestimates BMR (see Table 2).

More recently, Clark and Hoffer $^{27}$ who measured BMR in 18-30 year old men either using a Deltatrac (open circuit) or a 9 litre respirometer (similar to a Benedict-Roth closed circuit apparatus), found that the ventilated hood measurements produced a BMR of $6.87 \pm 0.619 \mathrm{MJ} / 24 \mathrm{~h} \quad(1643 \pm 148 \mathrm{kcal} / 24 \mathrm{~h}) \quad$ compared to $7.19 \pm 0.606 \mathrm{MJ} / 24 \mathrm{~h}(1721 \pm 145 \mathrm{kcal} / 24 \mathrm{~h})$ in the

Table 1 Measurement reliability and reproducibility using indirect calorimetry

\begin{tabular}{|c|c|c|c|c|c|c|c|}
\hline & $\begin{array}{c}\text { Oxylog } \\
\left(\text { kcal day }^{-1}\right)\end{array}$ & $\begin{array}{l}\text { HB metabolator } \\
\left(\mathrm{kcal} \mathrm{day}^{-1}\right)\end{array}$ & $\begin{array}{l}\text { Ventilated hood } \\
\quad\left(\text { kcal day }^{-1}\right)\end{array}$ & $\begin{array}{l}\text { Ventilated tent } \\
\quad\left(\text { kcal day }^{-1}\right)\end{array}$ & $\begin{array}{l}\text { Whole-body } \\
\text { calorimeter } \\
\text { (kcal day }^{-1} \text { ) }\end{array}$ & Difference (\%) & $\begin{array}{l}\text { Power } \\
\text { of } t \text { test }\end{array}$ \\
\hline Protocol 1 (n 6) & $1386.23 \pm 83.65$ & - & - & $1367.11 \pm 81.26$ & - & $+1.6 \pm 2.5$ & 0.07 \\
\hline Protocol 2 (n 6) & - & $1460.33 \pm 64.53$ & $1515.30 \pm 93.21$ & - & - & $-3.1 \pm 2.5$ & 0.15 \\
\hline Protocol 3 (n 6) & $1364.72 \pm 59.75$ & $1379.10 \pm 62.14$ & - & - & - & $-0.9 \pm 1.9$ & 0.05 \\
\hline Protocol 4 (n 6) & - & $1412.52 \pm 59.75$ & $1410.13 \pm 74.09$ & - & - & $+0.4 \pm 2.5$ & 0.03 \\
\hline Protocol 5 (n 10) & - & - & $1321.70 \pm 45.41$ & - & $1367.11 \pm 57.36$ & $-3.1 \pm 2.8$ & 0.15 \\
\hline
\end{tabular}


Table 2 Comparison between closed and open circuit BMR

\begin{tabular}{llc}
\hline Authors & No. of subjects & \multicolumn{1}{c}{ Difference } \\
\hline $\begin{array}{l}\text { Krogh and } \\
\text { Rasmussen (1922) } \\
\text { Hunt (1926) }\end{array}$ & 5 of 19 & $\begin{array}{c}6-11 \% \text { of open circuit } \\
\text { values }\end{array}$ \\
$\begin{array}{l}\text { Lewis et al. (1943) } \\
\text { values of open circuit } \\
\text { values }\end{array}$ & $\begin{array}{c}5 \% \text { of open circuit } \\
\text { values }\end{array}$ \\
Willard and Wolf (1951) & 8 of $18^{*}$ & $\begin{array}{c}10 \% \text { of open circuit } \\
\text { values }\end{array}$ \\
Fowler et al. (1957) & $52^{*}$ & $\begin{array}{c}\text { SD } 7 \% \text { of open circuit } \\
\text { values }\end{array}$ \\
Harmin (1953) & - & $\begin{array}{c}\text { SD } 7 \% \text { of open circuit } \\
\text { values }\end{array}$ \\
\hline
\end{tabular}

Abbreviation: BMR - basal metabolic rate.

Source: Consolazio et $a .^{26}$

${ }^{*}$ Adults.

closed circuit respirometer. These values indicate that the closed circuit apparatus produced a BMR 5.6\% higher than the open circuit.

\section{Summary}

1. Closed circuit calorimetry was widely used in the measurement of BMR during the first half of the 20th century.

2. Closed circuit calorimetry tended to produce higher BMR values.

3. The elevated values were ascribed to:

(a) Small leaks causing a larger error in the closed circuit calorimetry $^{28}$.

(b) The respiration of pure oxygen tended to elevate $\mathrm{BMR}^{16}$.

(c) Changes in chest volume during respiration tended to alter the slope of the spirogram reading, leading to an apparently higher BMR value ${ }^{22}$.

\section{Brief review of BMR standards and predictive equations}

This section briefly reviews the predictive equations for BMR in man beginning with the 'surface area law' at the turn of the 20th century to the more recent analysis by Schofield et al. ${ }^{29}$

\section{DuBois height-weight formula chart}

While surface area may be calculated using various anthropometric parameters, DuBois and DuBois ${ }^{30}$ produced an equation relating weight and height to surface area as follows:

$$
\mathrm{A}=\mathrm{W}^{0.425} \times \mathrm{H}^{0.715} \times 71.84
$$

where, $\mathrm{A}=$ surface area in $\mathrm{cm}^{2} ; \mathrm{W}=$ weight in kilograms and $\mathrm{H}=$ height in centimeters.

Later, Aub and DuBois ${ }^{3,4}$, applying the surface law principle to man, published a table of $\mathrm{BMR} \mathrm{m}^{-2}$ per hour from 14 to 80 years of age (Table 3). These formulae are still widely used despite being based on a group with only nine subjects and one cadaver!

\section{Harris-Benedict standards}

While the 'surface law' remained a dominant concept since its introduction early in the 20th century, it was nevertheless strongly challenged by Harris and Benedict ${ }^{11}$ who embarked on a detailed biometric analysis of BMR which culminated in the publication of their monumental work entitled A Biometric Study of Basal Metabolism in Man. BMR measurements were made on 136 males and 103 females at the Carnegie Nutrition Laboratory in Boston. Using rigorous statistical concepts, they developed the following equations to predict BMR:

males $\mathrm{h}=66.4730+13.7516 \mathrm{~W}+5.0033 \mathrm{~S}-6.7750 \mathrm{~A}$

females $\mathrm{h}=665.0955+9.5634 \mathrm{~W}+1.8496 \mathrm{~S}-4.6756 \mathrm{~A}$

where, $\mathrm{h}=\mathrm{kcalday}^{-1} ; \mathrm{W}=$ weight in kilograms; $\mathrm{S}=$ stature in centimeters; $\mathrm{A}=$ age in years.

Harris and Benedict's analysis marked a significant departure from previous work. Firstly, it introduced for the first time biometric principles in its analysis. Secondly, they used subjects that were maintained under strict experimental conditions prior to the measurements. Using partial correlation coefficients, they also showed that both stature and weight have an independent effect on BMR. While these equations were useful and valuable aids to predicting BMR, they were not above criticism. For example, the constant in the equation showed a ten-fold difference between males and females (66 versus 665). Benedict himself later recognised and expressed concern that the equations overestimated BMR, 'particularly in those young women'. Daly et $a l^{31}$ confirmed that the Harris-Benedict equations overestimated BMR by about 10-15\%. Despite this, the simplicity of the HarrisBenedict equation made it a popular equation in wide use. Even today, many clinicians in North America use it routinely ${ }^{32}$.

Table 3 DuBois normal standards for BMR (Cal m${ }^{-2}$ per hour)

\begin{tabular}{ccc}
\hline Age $(\mathrm{y})$ & Males & Females \\
\hline $14-15$ & 46.0 & 43.0 \\
$16-17$ & 43.0 & 40.0 \\
$18-19$ & 41.0 & 38.0 \\
$20-29$ & 39.5 & 37.0 \\
$30-39$ & 39.5 & 36.5 \\
$40-49$ & 38.5 & 36.0 \\
$50-59$ & 37.5 & 35.0 \\
$60-69$ & 36.5 & 34.0 \\
$70-79$ & 35.5 & 33.0 \\
\hline
\end{tabular}

Abbreviation: BMR - basal metabolic rate. 


\section{Boothby and Sandiford or 'Mayo standards'}

Scientists at the Mayo clinic commenced collecting BMR data systematically in a variety of subjects from 1917. The investigators used a combination of normal, free-living subjects and 'hospital normal' subjects. While the subjects admitted to hospital were not seriously ill, they nevertheless highlight the point that the subjects were not all 'normal' free-living subjects ${ }^{33,34}$. Boothby et al. ${ }^{15}$ made a careful study of BMR in 639 males and 828 females.

\section{Quenouille standards}

Quenouille et al.'s ${ }^{35}$ analysis in 1951 was the first comprehensive survey of all the available BMR studies conducted and represented over 8600 subjects ( 4300 aged between 17 and 39 years, 800 over 40 years and 3520 less than 1 year of age). We need to pay tribute to these investigators who were 'pioneers' in the systematic collection of BMR and they statistically analysed the data prior to the advent of computers. Quenouille et al.'s $\mathrm{s}^{35}$ extensive review of the early literature on BMR has also been a major source of valuable information for both the Schofield and Oxford databases. For the first time, Quenouille et $a l^{35}$ also included BMR measurements from people living in the tropics. Their analysis attempted to examine the role of ethnicity and climate on BMR. This made it the first large-scale study of the world literature on BMR. While they considered temperature and humidity as important factors in predicting BMR, sadly their equations were not used extensively. Given below is an example of their equation for men in Northern Europe.

$$
\mathrm{M}=2.975 \mathrm{H}+8.90 \mathrm{~W}+11.7 \mathrm{~S}+3.0 \mathrm{~h}-4.0 \mathrm{t}+293.8
$$

where, $\mathrm{M}=\mathrm{kcal}_{\mathrm{day}}{ }^{-1} ; \mathrm{W}=$ weight in kilograms; $\mathrm{H}=$ height in centimeters; $\mathrm{S}=$ surface area from DuBois; $\mathrm{t}=$ temperature and $\mathrm{h}=$ humidity.

\section{Schofield equations (FAO/WHO/UNU equations): issues and analysis}

Note here that the term FAO/WHO/UNU equations and Schofield equations will be used interchangeably. To facilitate the $1981 \mathrm{FAO} / \mathrm{WHO} / \mathrm{UNU}$ expert consultation on Energy and Protein Requirements, Durnin ${ }^{16}$ surveyed the literature on BMR and assembled BMR values and anthropometric data on 2238 subjects. Durnin ${ }^{16}$ presented tables to predict BMR based on body weight, age and gender. Subsequently, the FAO/WHO/UNU requested Schofield et $a l^{29}$ to extend this analysis and produce a series of predictive equations. Schofield et al. ${ }^{29}$ reviewed the literature and produced predictive equations for both sexes for the following ages: $0-3,3-10,10-18,18-30$, $30-60$ and $>60$ years. These formed the basis for the equations used in the FAO/WHO/UNU document Energy and Protein Requirements ${ }^{1}$. The Schofield database
Table 4 The percentages by which the FAO/WHO/UNU equations overestimate $(+)$ or underestimate $(-)$ the actual BMR in different ethnic groups

\begin{tabular}{lcc}
\hline Age group $(\mathrm{y})$ & Mean $\%$ & No. of subjects \\
\hline Males (all ethnicities) & & \\
$3-10$ & +1.9 & 196 \\
$10-18$ & +7.1 & 409 \\
$18-30$ & +10.3 & 1174 \\
$30-60$ & +11.2 & 274 \\
$3-60$ & +9.0 & 2053 \\
Females (all ethnicities) & & \\
$3-10$ & +1.5 & 88 \\
$10-18$ & +7.6 & 233 \\
$18-30$ & +3.8 & 350 \\
$30-60$ & +9.7 & 98 \\
$3-60$ & +5.4 & 769 \\
All ethnicities, all ages, both sexes & +8.0 & 2822 \\
\hline
\end{tabular}

Abbreviations: FAO/WHO/UNU - Food and Agriculture Organization/World Health Organization/United Nations University; BMR - basal metabolic rate.

Source: Henry and Rees ${ }^{37}$.

comprised 114 published studies of BMR, totalling 7173 data points. Although their database comprised almost 11000 BMR values (including group mean values), most of the results were obtained from European and North American subjects. An interesting feature that emerged from their analysis was that the BMR of Asiatic Indians was overestimated by $10-11 \%$ by their equations. This issue was further highlighted by the FAO/WHO/UNU report. At the time of their analysis, there was insufficient data to ascertain whether the effect noted in Indians was unique or whether it reflected a general pattern of metabolism in tropical peoples. Indeed, the observation that BMR may be different in peoples living in the tropics was first reported by de Almeida ${ }^{36}$. He showed that BMR in Brazilians was approximately $24 \%$ lower than the Aub-DuBois standards. Subsequently, Henry and Rees ${ }^{37}$ showed that the FAO/

Table 5 The percentage by which the FAO/WHO/UNU equations overestimate $(+)$ or underestimate $(-)$ BMR in different ethnic groups by sex, all ages $3-60$ years

\begin{tabular}{lrrrrr}
\hline & \multicolumn{3}{c}{ Male } & & \multicolumn{2}{c}{ Female } \\
\cline { 2 - 3 } \cline { 5 - 6 } Ethnicity & Mean \% & Sample size & & Mean \% & Sample size \\
\hline Philippino & +9.5 & 172 & & +1.1 & 31 \\
Indian & +12.8 & 50 & & +12.9 & 7 \\
Japanese & +5.8 & 202 & & +4.6 & 152 \\
South American & +9.4 & 941 & & +4.8 & 227 \\
Chinese & +7.6 & 274 & & +3.8 & 190 \\
Malayan & +9.3 & 62 & & No data & \\
Javanese & +5.0 & 86 & & No data & \\
Mayan & +1.5 & 76 & & No data & \\
Ceylonese & +22.4 & 125 & & +12.5 & 100 \\
African & +6.5 & 20 & & No data & \\
Hawaiian & +7.2 & 19 & & +4.5 & 62 \\
Samoan & +3.3 & 21 & No data & \\
All & +9.0 & 2053 & & +5.4 & 769 \\
\hline
\end{tabular}

Abbreviations: FAO/WHO/UNU - Food and Agriculture Organization/World Health Organization/United Nations University; BMR - basal metabolic rate.

Source: Henry and Rees ${ }^{37}$. 
WHO/UNU equations overestimated BMR in a range of tropical populations (see Tables 4 and 5).

While Schofield's analysis has served a significant role in re-establishing the importance of using BMR to predict human energy requirements, recent workers have subsequently queried the universal validity and application of these equations ${ }^{38-43}$. Other authors ${ }^{44,45}$ have questioned the equations' continued use in present day populations with their secular changes in body weight and body composition $^{46-48}$. In contrast to the previous observation that the $\mathrm{FAO} / \mathrm{WHO} / \mathrm{UNU}$ equations overestimated BMR in tropical people ${ }^{49}$, further analysis shows that the FAO/ WHO/UNU equations tend to overestimate BMR in most populations and these overestimations are not small or insignificant (see Tables 6 and 7). A detailed analysis of the over- and underestimation in BMR using the FAO/WHO/ UNU equations observed in children aged $2.5-18$ years was reported by several investigators ${ }^{50-53}$. These children were studied in a range of countries, including Columbia, Guatemala and China. While all of the above studies reported an overestimation of BMR in these children, the studies by Livingstone et $a l .{ }^{54}$ reported an underestimation and Bandini et al. ${ }^{55}$ no significant difference when the FAO/ WHO/UNU equations were used. BMR studies conducted more recently have also shown that the predicted values using the $\mathrm{FAO} / \mathrm{WHO} / \mathrm{UNU}$ equations overestimate BMR in Asian and Chinese subjects ${ }^{56,57}$. For example, in the study by Leung et $a{ }^{57}$ the $\mathrm{FAO} / \mathrm{WHO} / \mathrm{UNU}$ equation overestimated BMR from the measured values by up to $456 \pm 67 \mathrm{~kJ}$ (measured BMR 5.025 $\pm 0.967 \mathrm{MJ}$; predicted

Table 6 Comparison of BMR values from the literature: observed values vs. predicted values using the Schofield equations

\begin{tabular}{|c|c|c|c|c|c|c|c|}
\hline Investigator & Year & Subjects & Age range $(y)$ & Male & Female & Total & $\%$ difference \\
\hline Owen et al. & 1986 & $\begin{array}{l}\text { Mixed Race } \\
\text { Americans }\end{array}$ & $18-65$ & - & 34 & 34 & +11 \\
\hline Owen et al. & 1987 & $\begin{array}{l}\text { Mixed Race } \\
\text { Caucasians } \\
\text { African-American } \\
\text { Oriental }\end{array}$ & $18-82$ & 48 & - & 48 & +5 \\
\hline Soares and Shetty & 1988 & $\begin{array}{l}\text { Indian } \\
\text { Urban upper socio-econ } \\
\text { Urban lower socio-econ } \\
\text { Rural }\end{array}$ & $18-30$ & $\begin{array}{r}123 \\
47 \\
36 \\
40\end{array}$ & & 123 & $\begin{array}{c}+9.3 \\
+6.6 \\
+12.9 \\
\text { Range }+5.5-12.6\end{array}$ \\
\hline Mifflin et al. & 1990 & $\begin{array}{l}\text { Mixed Race } \\
\text { Americans }\end{array}$ & $19-78$ & 251 & 247 & 498 & $\begin{array}{l}+6.2 \text { (males) } \\
+2.2 \text { (females) }\end{array}$ \\
\hline Spurr et al. & 1992 & $\begin{array}{l}\text { Colombian } \\
\text { Males } \\
\text { Females }\end{array}$ & $\begin{array}{r}2-16 \\
3-10 \\
10-18 \\
3-10 \\
10-18\end{array}$ & 153 & 93 & 246 & $\begin{array}{l}\text { Range } \\
+2.7-9.4 \\
+2.5 \\
+9.4 \\
+1.4\end{array}$ \\
\hline \multirow[t]{5}{*}{ Maffeis et al. } & 1993 & $\begin{array}{l}\text { Italian } \\
\text { Males }\end{array}$ & $6-10$ & 62 & 68 & 130 & No \\
\hline & & Non-obese & & 48 & - & & Difference \\
\hline & & $\begin{array}{l}\text { Obese } \\
\text { Females }\end{array}$ & & 14 & - & & +15.3 \\
\hline & & Non-obese & & - & 49 & & +8.0 \\
\hline & & Obese & & - & 19 & & +20.0 \\
\hline Rieper et al. & 1993 & German & $14-15$ & - & 11 & 11 & No difference \\
\hline Valencia et al. & 1993 & Mexican & $18-40$ & 32 & - & 32 & +8.2 \\
\hline \multirow[t]{3}{*}{ Fontville and Ravussin } & 1993 & Mixed Race & $7-12$ & & & & \\
\hline & & Caucasian & & 21 & 21 & 42 & No difference \\
\hline & & Pima Indian & & 22 & 21 & 43 & +6.7 \\
\hline \multirow[t]{3}{*}{ Piers and Shetty } & 1993 & Indian & $18-30$ & - & 60 & 60 & +9.2 \\
\hline & & Past Indian Study & & - & 52 & & +10.5 \\
\hline & & European/American & & - & 52 & & +4.1 \\
\hline \multirow[t]{5}{*}{ Molnar et al. } & 1995 & $\begin{array}{l}\text { Hungarian } \\
\text { Males }\end{array}$ & $10-16$ & 193 & 178 & 371 & \\
\hline & & Non-obese & & 116 & - & & +7.8 \\
\hline & & $\begin{array}{l}\text { Obese } \\
\text { Females }\end{array}$ & & 77 & - & & +13.4 \\
\hline & & Non-obese & & 119 & - & & +8.0 \\
\hline & & Obese & & 59 & - & & +5.8 \\
\hline Liu et al. & 1995 & Chinese & $20-78$ & 102 & 121 & 223 & $\begin{array}{l}+15.1 \text { (males) } \\
+17.9 \text { (females) }\end{array}$ \\
\hline \multirow[t]{3}{*}{ Wong et al. } & 1996 & Mixed Race & $8-17$ & - & 118 & 118 & \multirow{4}{*}{$\begin{array}{l}\text { No difference } \\
\quad+8 \\
\quad+5.3 \text { (males) } \\
+2.2 \text { (females) }\end{array}$} \\
\hline & & Caucasian & & - & 76 & & \\
\hline & & African-American & & - & 42 & & \\
\hline Piers et al. & 1997 & Australian & $18-30$ & 39 & 89 & 128 & \\
\hline
\end{tabular}


Table 7 Contribution of Italian subjects to Schofield database

\begin{tabular}{lcccc}
\hline Gender & Age $(\mathrm{y})$ & Italians $(n)$ & Schofield $(n)$ & $\begin{array}{c}\text { Percentage } \\
\text { of total }\end{array}$ \\
\hline Males & $0-3$ & 0 & 162 & 0.0 \\
& $3-10$ & 158 & 338 & 46.7 \\
& $10-18$ & 472 & 734 & 64.3 \\
& $18-30$ & 1740 & 2879 & 60.4 \\
& $30-60$ & 392 & 646 & 60.7 \\
& $60+$ & 0 & 50 & 0.0 \\
Females & Total & 2762 & 4809 & 57.4 \\
& $0-3$ & 0 & 137 & 0.0 \\
& $3-10$ & 220 & 413 & 53.3 \\
& $10-18$ & 167 & 575 & 29.0 \\
& $18-30$ & 135 & 829 & 16.3 \\
& $30-60$ & 106 & 372 & 28.5 \\
& $60+$ & 6 & 38 & 15.8 \\
& Total & 634 & 2364 & 26.8 \\
\hline
\end{tabular}

$5.481 \pm 0.845 \mathrm{MJ})$. Recently, Piers et al. ${ }^{58}$ reported that the FAO/WHO/UNU equations overestimated BMR in male and female Australians.

A survey of the most recent studies (1980-2000) in BMR suggests that in most cases the current FAO/WHO/UNU predictive equations overestimate BMR in many communities. The few exceptions to this general trend are the reports by Bandini et al. ${ }^{55}$ Livingstone et al., ${ }^{54}$ Ferro-Luzzi et $a l .{ }^{59}$ and Yamauchi et al. ${ }^{60}$. These authors either showed an underestimation or good agreement with the FAO/ WHO/UNU equations. Contrary to the popular view that only people in the tropics may have lower BMR, the recent study by Wong et ll $^{43}$ showed that BMR in AfricanAmerican children aged 8-17 years was 7\% lower than that predicted by the FAO/WHO/UNU equations. Whatever the reasons for these varied observations, it is clear that the present $\mathrm{FAO} / \mathrm{WHO} / \mathrm{UNU}$ equation tends to overpredict BMR in many communities.

Another significant feature of the Schofield database was that for males aged between 10 and 60 years, over 3000 (50\%) data points come from Italian subjects. The Italian group appear to have a higher BMR per kilogram than any other Caucasian group ${ }^{49,41}$. More importantly, the inclusion of this disproportionately large Italian group with a higher BMR per kilogram may have artificially elevated the Schofield predictive equations. Indeed this view was first expressed by Schofield ${ }^{29}$. He wrote:

'The equation for adult males and females (18-30) were recalculated excluding Italian subjects. The new equations were:

$$
\begin{aligned}
& \text { Males: } \quad \operatorname{BMR}(\mathrm{MJ} / 24 \mathrm{~h})=0.0582 \mathrm{~W}+3.2399 \\
& \text { SEE }=0.6148 \\
& \text { Females: } \quad \operatorname{BMR}(\mathrm{MJ} / 24 \mathrm{~h})=0.0545 \mathrm{~W}+2.5135 \\
& \text { SEE }=0.4813
\end{aligned}
$$

When these equations were used to predict BMR for Italian subjects there was a highly significant lack of fit for both males and females'.

The applicability and use of body weight to predict BMR in various populations depends on the assumption that a similarity in body composition exists between the surveyed database and the test population applied to. It is increasingly clear that the subjects from whom the BMR database (originally from data gathered over 80-90 years ago) was assembled had a different body composition to that seen today (Norgan) ${ }^{61}$. The discussion and debate surrounding the use and application of the BMR equations were summarised by Soares et $a l .{ }^{44}$ as follows:

"Whatever the reason it is becoming increasingly evident that the equations of Schofield derived from measurements made over 60 years ago are not at present valid for the precise prediction of BMR of population groups worldwide'.

\section{Contribution of Italian subjects to the Schofield database}

A closer examination of the Italian data points in the Schofield database reveals some issues of major concern. The Italian group represented 3388 BMR data points from a total of 7173 values in the Schofield database. These 3388 BMR values for Italians came from just nine papers that were published between 1936 and 1942 and contributed $60-64 \%$ of the Schofield database, depending on the age group under consideration (see Table 7).

A significant feature of the Schofield database was that it shared a large proportion of the original database initially identified by Quenouille et al. ${ }^{35}$ Table 8 illustrates this point.

The Schofield database contained the same nine Italian papers first identified by Quenouille et $a l^{35}$ Quenouille analysis $^{35}$ delineated four populations: North European and Americans; Italians; Asians; and a 'residual mixed group'. Within these groups, Italians had the highest BMR per kilogram. Schofield et al. ${ }^{29}$ also noted a similar higher BMR per kg in the Italians. Since the 18-30 year old male group in the Schofield database contained the largest number of Italian subjects (1740 out of a total of 2879), this group may be further analysed when matched for body size and body mass index (BMI).

Table 9 shows weight, height, BMR and BMR per kilogram in BMI-matched Italian and North European and American subjects in the Schofield database. What is clear is that the Italian subjects show an elevated BMR $\left(\mathrm{MJday}{ }^{-1}\right.$ or $\mathrm{kJ} \mathrm{kg}^{-1}$ per day) when also matched for $\mathrm{BMI}^{62}$

Table 8 Papers and data points shared by Schofield ${ }^{29}$ and Quenouille et al. ${ }^{35}$

\begin{tabular}{lcc}
\hline Investigator & $\begin{array}{c}\text { Number } \\
\text { of papers }\end{array}$ & $\begin{array}{r}\text { Number of } \\
\text { data points }\end{array}$ \\
\hline Quenouille & 89 & 7434 \\
Schofield & 114 & 7173 \\
$\begin{array}{l}\text { Papers common to Quenouille } \\
\text { and Schofield }\end{array}$ & 50 & 6124 \\
\hline
\end{tabular}


Table 9 Wilcoxon U-tests of weight, height, BMR and BMR kg-1 in BMI matched Italian and North European and American (NE\&A) subjects in the Schofield database

\begin{tabular}{|c|c|c|c|c|c|c|}
\hline BMI range & Group & $n$ & $\begin{array}{l}\text { Weight } \\
\text { (kg) }\end{array}$ & $\begin{array}{l}\text { Height } \\
\text { (m) }\end{array}$ & $\begin{array}{c}\text { BMR } \\
\left(\mathrm{MJ} \mathrm{day}^{-1}\right)\end{array}$ & $\begin{array}{c}\text { BMR } \\
\text { (kJ kg }^{-1} \\
\text { per day) }\end{array}$ \\
\hline \multirow[t]{2}{*}{$18.0-18.9$} & NE\& & 36 & 54.8 & 1.7 & 6279 & 11 \\
\hline & & 29 & & 1 & 0 & 0 \\
\hline \multirow[t]{2}{*}{$19.0-19.9$} & NE\&A & 63 & 58.4 & 1.73 & 46 & 111 \\
\hline & & 78 & $56.5^{*}$ & $1.70^{*}$ & $0^{\star \star \star \star}$ & $122^{\star \star *}$ \\
\hline \multirow[t]{2}{*}{$20.0-20.9$} & NE\&A & 78 & 61.8 & 1.74 & 6635 & 107 \\
\hline & Italian & 218 & $59.6^{\star \star \star}$ & $1.70^{\star \star \star}$ & $6966^{\star *}$ & $117^{\star \star \star}$ \\
\hline \multirow[t]{2}{*}{$21.0-21.9$} & NE\&A & 85 & 66.2 & 1.75 & 6932 & 105 \\
\hline & Italian & 313 & $62.1^{* \star *}$ & $1.70^{\star * *}$ & & $113^{\star \star \star}$ \\
\hline \multirow[t]{2}{*}{$22.0-22.9$} & NE\&A & 59 & 68.1 & 1.74 & 6932 & 102 \\
\hline & Italian & 314 & $65.3^{\star \star \star}$ & $1.71^{\star \star \star}$ & $7204^{*}$ & $110^{\star * \star}$ \\
\hline \multirow[t]{2}{*}{$23.0-23.9$} & NE\&A & 38 & 71.8 & 1.7 & & 101 \\
\hline & Ita & 298 & $67.9^{\star \star \star}$ & $1.70^{\star \star \star}$ & 72 & 107 \\
\hline \multirow[t]{2}{*}{$24.0-24.9$} & NE\&A & 18 & 74.7 & 1.75 & 7217 & 97 \\
\hline & & 155 & $70.6^{*}$ & 1.70 & 7480 & $106^{\star \star}$ \\
\hline \multirow[t]{2}{*}{$25.0-25.9$} & NE\&A & 8 & 73.9 & 1.70 & 7208 & 98 \\
\hline & Italian & 53 & 72.3 & 1.69 & 7468 & 103 \\
\hline
\end{tabular}

Abbreviations: BMR - basal metabolic rate; BMI - body mass index. Significant difference: ${ }^{\star} P<0.05 ;{ }^{* \star} P<0.01 ;{ }^{* \star *} P<0.001$. Source: Hayter and Henry ${ }^{63}$.

The results of this analysis suggest that previous studies appear to have either overlooked or ignored such large population differences in BMR per kilogram observed in the Italians. The nine papers from the Italian investigators used in the Schofield analysis are shown in Table 10.

All of the Italian studies used the Benedict-Roth spirometer, an indirect closed circuit method. Our earlier review has suggested that closed circuit methods are more likely to lead to higher BMR values compared to open circuit. The subjects used in the Italian studies were primarily young, the males tending to lead physically active lives. This is especially so in the case of labourers and miners; these occupations are known to have very high rates of daily energy expenditure. The work of Poehlman et $a l^{64}{ }^{6}$ indicates that physically active individuals have higher BMRs compared to sedentary lifestyles. Whatever the reasons for the elevated BMR noted in the Italians, their numerical dominance in the Schofield database may largely explain why the Schofield equations (FAO/WHO/UNU equations) overestimate BMR in present day populations.

\section{Summary}

A need to re-assess the FAO/WHO/UNU equations to predict $\mathrm{BMR}$ is prompted by the following:

1. The current $\mathrm{FAO} / \mathrm{WHO} / \mathrm{UNU}$ equations appear to overestimate BMR in many populations (both in tropical and temperate regions). Some studies, however, show good agreement with the FAO/ WHO/UNU equations.

2. If $B M R$ values are to be used to estimate total energy requirements for prescriptive and diagnostic purposes (in both individuals and populations), any overestimation in BMR is likely to produce misleading estimates of energy requirements.

3. The $\mathrm{FAO} / \mathrm{WHO} / \mathrm{UNU}$ equations to predict $\mathrm{BMR}$ were developed using a database that contained a disproportionate number - 3388 out of 7173 (47\%) - of Italian subjects.

4. These Italian subjects had a higher BMR per kilogram than any other group in the Schofield database.

5. The numerical dominance of Italians in the Schofield database and their apparent elevated BMR recorded may largely explain why the Schofield equations overestimate BMR in most populations today.

6. It is recommended that the Italian database be removed from any future analysis as (1) they have unusually high BMR values (even when normalised for body weight and BMI); (2) they are overrepresented in the Schofield database; and (3) their over-representation has meant by definition an under-representation of other world populations.

7. The Schofield database contained relatively few subjects from the tropical region (322 Indian and 615 tropical residents) making it a poor representation of the global population.

8. The primary purpose of collecting BMR measures during the early part of the 20th century was to diagnose hypo- and hyperthyroidism.

9. The primary purpose of collecting BMR measures in recent years has been to estimate total energy requirements or to better understand energy regulation.

Table 10 Italian data used in the Schofield database ${ }^{29}$

\begin{tabular}{lclcl}
\hline Study & $n$ & Gender & Age $(\mathrm{y})$ & \multicolumn{1}{c}{ Subject details } \\
\hline Felloni (1936) & 532 & Male & $19-25$ & Students of the Royal Fascist Academy \\
Granti and Busca (1941-1942) & 186 & Male & $16-55$ & Labourers and miners on shift work \\
Lafratta (1937) & 213 & Male & $14-20$ & Students of Naples Royal Military College \\
Lenti (1937) & 525 & Male & $20-25$ & Military servicemen \\
Occhiuto and Pepe (1939) & 247 & Female & $20-67$ & Different social groups \\
Occhiuto and Pepe (1940) & 571 & Male & $22-54$ & Police officers \\
Pepe (1938) & 252 & Male & $18-24$ & Students of Royal Naval Academy \\
Pepe and Perrelli (1937) & 267 & Male & $5-16$ & No details \\
Pepe and Rinaldi (1936) & 235 & Female & $5-12$ & No details \\
& 217 & Male & $6-16$ & No details \\
Total & 143 & Female & $5-12$ & No details \\
\hline
\end{tabular}


10. This change of emphasis and role of BMR has placed it within a different nutritional paradigm.

11. If BMR equations are to be used and applied worldwide, the database must contain a more representative sample of the world population.

The objective of all consultations is to scientifically progress and identify fresh ideas and issues. Many of the technological advances that have emerged during the past few years have enabled the measurement of BMR to be conducted with ease and reproducibility. This is an opportune moment to re-examine the role and place of BMR measurements in estimating total energy requirements today, using a more representative world population base.

\section{Development of the Oxford database}

\section{Initial selection criteria for BMR data in the Oxford} Database: preliminary screening

There has been considerable disagreement in the literature as to the 'best' way in which BMR data should be selected and collected.

The four methods used to 'accept' values for BMR reported in the literature include:

1. Mean of all determinations (the BMR of the subject was taken as the mean of all determinations taken on the subject).

2. First determination (only the first observation was considered).

3. Lowest of all determinations (only the lowest value was chosen).

4. Mean of the lower of three duplicates (the lower values in each of the 3 days were averaged and taken as the BMR of the subject).

While an element of training has been considered by several investigators as an important factor in BMR determinations, the BMR report by Robertson and Reid ${ }^{65}$ from a large study in Britain has been excluded from wide use as the investigation used the lowest values recorded after several bouts of collection. Durnin ${ }^{16}$ suggested that no significant effect was produced by the method of selection of BMR data with the exception of including lowest BMR results. Apart from excluding BMR values that were reported as lowest values, all other BMR values were initially considered for inclusion in the Oxford survey, prior to further screening.

\section{Computation of new BMR equations (Oxford equations)}

\section{Oxford data compendium}

Once such papers were identified (as outlined above), the literature search produced numerous papers on BMR. Much of the identification of the early studies on BMR was done by hand search. This was supplemented by using
MEDLINE. As papers began to accumulate, it rapidly became clear that the quantity of data gathered was uneven. The research methods presented the description of subjects and conditions varied from complete details to no information. To preserve uniformity and to meet the criteria defining basal metabolism, it was decided to include data for further analysis only if the following information was provided in the papers:

1. Age, weight, gender of subjects

2. Description of experimental conditions and equipment used to measure BMR.

3. Post-absorptive, rested subjects.

4. Subjects that were described as 'healthy' (i.e. not suffering from any illness).

5. Location/ethnicity of subjects.

Reasons for rejecting data for further analysis included the following:

1. BMR presented only in terms of surface area (no height or weight provided), therefore $\mathrm{BMR} / 24$ hours could not be calculated.

2. BMR presented as a percentage deviation of other standards (usually Harris-Benedict and DuBois).

3. BMR measured on malnourished or sick subjects.

4. BMR measured below $18^{\circ} \mathrm{C}$.

5. BMR measured at high altitudes.

6. BMR measured in subjects who had eaten or drunk coffee.

It was not possible to obtain information on the ambient temperature at the time of BMR measurements in all papers. However, in papers where temperature was described, if the ambient temperature was below $18^{\circ} \mathrm{C}$, such papers were rejected. In most papers, BMR was expressed as $\mathrm{kcal} \mathrm{day}^{-1}, \mathrm{~kJ} \mathrm{day}^{-1}, \mathrm{kcal} \mathrm{kg}^{-1}$ per day or $\mathrm{kcal} \mathrm{m}^{-2}$. When BMR was expressed as $\mathrm{O}_{2}$ consumption, with no RQ values reported, an energy equivalence of 4.9 was used. By the time the compilation was complete, data were available for 10552 subjects ( 5794 males and 4702 females). The data came from 166 separate investigations. In this analysis, only individual data points were used. Several studies that presented data as group means were excluded.

In the cases of researchers such as Benedict ${ }^{18,66-75}$, Lewis $^{20,76,77}$, Mason ${ }^{78-81}$, Nakagawa ${ }^{82-85}$, Wardlaw ${ }^{86-88}$ and Wang ${ }^{90-93}$, even if descriptive details were not provided in all their papers, they were included for further analysis as their protocol was detailed (and acceptable) in the first of their papers.

The Oxford database also excluded all the Italian subjects due to their unusually high BMR values. To ensure quality data for the equations to estimate BMR, further screening took place. All individual data was screened to identify errors of data input and transcription. Screening also allowed outlying or extreme cases to be identified and removed, if appropriate, from the database. As well as 


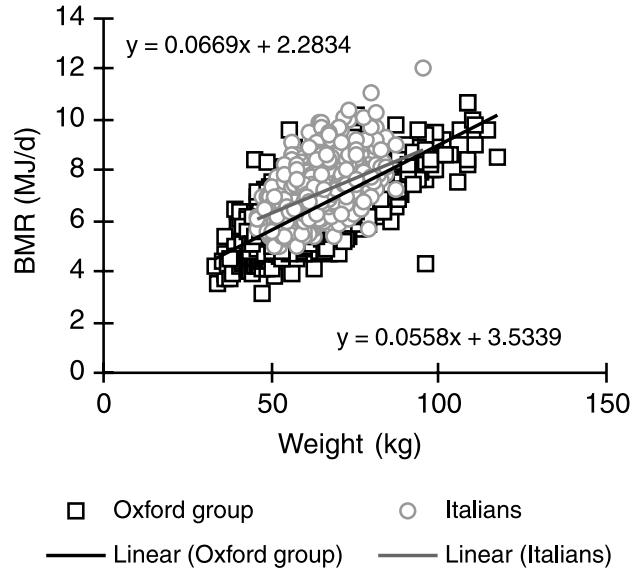

Fig. 1 Basal metabolic rate (BMR) vs. body weight - males 18-30 years

screening data on an individual basis, screening also took place at study level.

The value of a large database that draws on information collected by a wide range of investigators rests on the assumption that all investigators adopted a 'standard' practice to measure BMR - which clearly they did not. Although strict inclusion criteria had been used to develop the Oxford database, very similar to those adopted by Schofield et al $^{29}$, the fact that such criteria must, of necessity, rely on published reports of methods and protocol needs to be recognised.

\section{Computation of equations from Oxford database}

A series of plots of BMR against body weight were performed at six different age groups $(0-3$ years, 3-10 years, 10-18 years, 18-30 years, 30-60 years and $>60$ years) for males and females. Representative examples are shown in Figs 1-4. These represent BMR vs. body weight in the Oxford database and compares them with the Italian

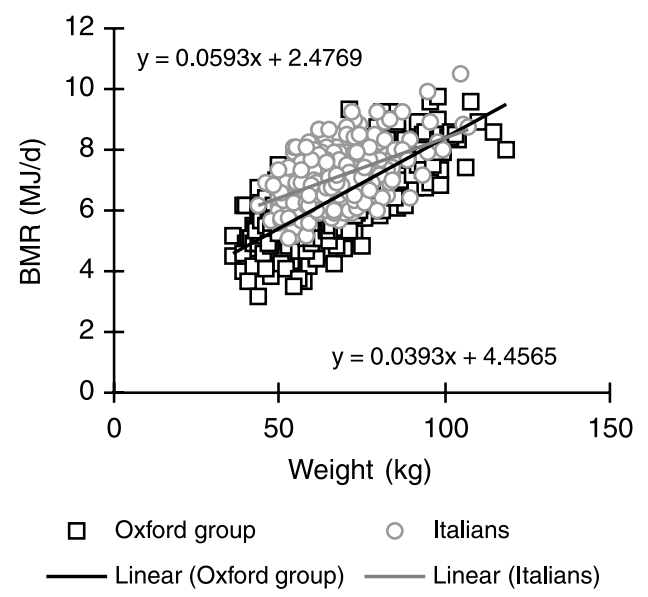

Fig. 2 Basal metabolic rate (BMR) vs. body weight - males $30-60$ years
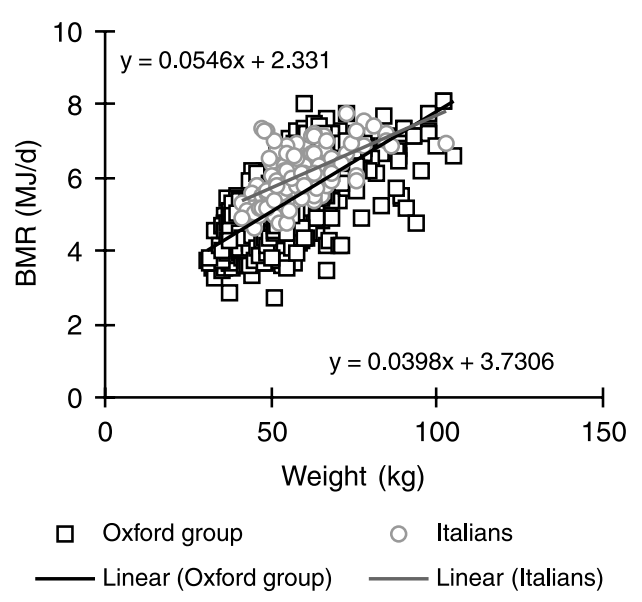

Fig. 3 Basal metabolic rate (BMR) vs. body weight - females 18-30 years

subjects for illustrative purposes. It is evident that the Italians once again show considerable difference with the Oxford trendline (Italian trendline - top line on figures; Oxford regression - top left-hand corner on figures).

To further substantiate why the Italian subjects have been excluded from the Oxford database, Table 11 shows descriptive statistics between the Italian subjects and the rest of the Oxford database. The age bands 10-18 years, 18-30 years and 30-60 years only were chosen for analysis as they contain the largest number of Italian subjects. It is evident that the Italian subjects show significant differences in BMR, even when expressed as $\mathrm{BMR}_{\text {day }}{ }^{-1}$ or BMR $/ \mathrm{kg} /$ body weight.

Table 12 contains the equations for predicting BMR from weight alone and descriptive statistics for the Oxford equations.

Equations to predict BMR from weight for six separate age groups and gender are presented in Table 13, along with the $\mathrm{FAO} / \mathrm{WHO} / \mathrm{UNU}$ equations for comparison.

Given that a reasonably large number of BMR values from elderly subjects were available, it was decided to 
Table 11 Comparison of descriptive statistics (mean $\pm \mathrm{SD}$ ) for Italian data vs. all data in Oxford database

\begin{tabular}{|c|c|c|c|c|c|c|c|}
\hline Gender & Age (y) & Source & Weight (kg) & Height $(m)$ & BMI & BMR ( $\mathrm{kJ} \mathrm{kg}^{-1}$ per day) & $\operatorname{BMR}\left(\mathrm{MJ} \mathrm{day}^{-1}\right)$ \\
\hline \multirow[t]{6}{*}{ Males } & \multirow[t]{2}{*}{$10-18$} & All ${ }^{1}$ & $40.0 \pm 12.5$ & $1.49 \pm 0.146^{\star *}$ & $17.7 \pm 2.65^{\star \star *}$ & $143 \pm 22.6^{\star \star *}$ & $5.51 \pm 1.11^{* \star *}$ \\
\hline & & Italian & $41.5 \pm 15.4$ & $1.47 \pm 0.171$ & $18.4 \pm 3.10$ & $151 \pm 26.8$ & $5.89 \pm 1.27$ \\
\hline & \multirow[t]{2}{*}{$18-30$} & All ${ }^{1}$ & $61.0 \pm 11.4^{\star \star *}$ & $1.70 \pm 0.0872$ & $20.9 \pm 2.84^{\star \star *}$ & $106 \pm 12.8^{\star \star \star}$ & $6.36 \pm 1.00^{\star \star *}$ \\
\hline & & Italian & $64.8 \pm 6.83$ & $1.70 \pm 0.0658$ & $22.4 \pm 1.79$ & $111 \pm 11.9$ & $7.15 \pm 0.767$ \\
\hline & \multirow[t]{2}{*}{$30-60$} & All ${ }^{1}$ & $65.3 \pm 13.0$ & $1.69 \pm 0.0942^{*}$ & $22.8 \pm 3.2^{*}$ & $98.7 \pm 13.6^{\star \star \star}$ & $6.35 \pm 1.03^{\star \star *}$ \\
\hline & & Italian & $65.6 \pm 10.3$ & $1.68 \pm 0.0538$ & $23.3 \pm 3.35$ & $109 \pm 14.5$ & $7.04 \pm 0.772$ \\
\hline \multirow{6}{*}{ Females } & \multirow[t]{2}{*}{$10-18$} & All ${ }^{1}$ & $43.4 \pm 12.9^{\star \star \star \star}$ & $1.50 \pm 0.113^{\star \star \star *}$ & $18.8 \pm 3.64^{\star \star *}$ & $126 \pm 24.1^{\star \star \star}$ & $5.20 \pm 0.797^{\star \star \star}$ \\
\hline & & Italian² & $28.4 \pm 4.42$ & $1.33 \pm 0.0690$ & $16.0 \pm 1.55$ & $155 \pm 17.5$ & $4.36 \pm 0.475$ \\
\hline & \multirow[t]{2}{*}{$18-30$} & All $^{1}$ & $53.2 \pm 10.0^{\star \star \star}$ & $1.60 \pm 0.0755^{\star \star \star}$ & $20.7 \pm 3.18^{\star \star \star}$ & $99.8 \pm 12.7^{\star \star \star}$ & $5.24 \pm 0.786^{\star \star \star}$ \\
\hline & & Italian & $58.0 \pm 10.3$ & $1.57 \pm 0.0612$ & $23.4 \pm 3.97$ & $106 \pm 14.3$ & $6.04 \pm 0.688$ \\
\hline & \multirow[t]{2}{*}{$30-60$} & All ${ }^{1}$ & $59.1 \pm 13.7$ & $1.59 \pm 0.0792^{\star \star \star}$ & $23.3 \pm 4.48^{\star \star \star \star}$ & $92.0 \pm 14.3^{\star \star \star}$ & $5.30 \pm 0.804^{\star \star \star}$ \\
\hline & & Italian & $60.7 \pm 13.0$ & $1.56 \pm 0.605$ & $25.0 \pm 5.00$ & $98.4 \pm 17.8$ & $5.72 \pm 0.605$ \\
\hline
\end{tabular}

Significant difference: ${ }^{\star} P<0.05 ;{ }^{\star \star} P<0.01 ;{ }^{* \star \star} P<0.001$.

${ }^{1}$ Excludes Italians

${ }^{2}$ Italian girls all just over 10 years.

break down the elderly group into 'young elderly' and 'older elderly' (see Table 14).

Figures 5-8 illustrate the relationship between body weight and BMR in the elderly groups.

While Table 13 contains equations for predicting BMR from weight alone, Table 15 contains equations using height and weight. To enable the comparison of the effect of including height as a second variable for males and females, the equations were re-calculated using weight/height as independent variables across the entire age range. Table 16 gives mean values and standard deviations for the various age groups in the Oxford analysis.

Any improvement in using height and weight to predict BMR was tested. Table 17 shows that no significant advantage was afforded in predicting BMR with the inclusion of height.

\section{Applications of new BMR equations}

Using the Oxford equations, BMR was calculated for a range of body weights and ages $(0-3,3-10,10-18$, $18-30,30-60,>60$ years) for both males and females (Tables 18 and 19). It is interesting to note that in adults the greatest differences in BMR were found in 18-30 and 30-60 year age groups within the lower body weight ranges $(<60 \mathrm{~kg})$ in males. There was a steadily increasing difference in BMR with decreasing body weight in these two age groups (18-30 and 30-60 years). For females, differences in BMR were seen in most of the body weight range notably in the age groups $18-30,30-60$ and $>60$ years. In the lower age groups ( $0-3$ years), the $\mathrm{FAO} / \mathrm{WHO} / \mathrm{UNU}$ equations appear to underestimate BMR, both in males and females. At 3-10 years of age, the FAO/WHO/UNU equations underestimate BMR in males and overestimate BMR in females. The differences in BMR assume significance when one considers that the lower body weights $(50-60 \mathrm{~kg}$ ) are those that are commonly observed in many developing countries. Moreover, the ages (18-60 years) that show the greatest differences in BMR are ages at which most populations are in a productive stage of occupational activity. Over- and under-prediction of BMR in these groups may have significant influences on estimating their energy requirements and hence food needs. Table 20 summarises these differences in BMR at various ages.

It is significant to note that the ages at which differences in BMR were recorded between the new Oxford equations

Table 12 Descriptive equations and statistics (mean \pm SD) of Oxford predictive equations for BMR

\begin{tabular}{lcccrrr}
\hline Gender & Age $(\mathrm{y})$ & MJ day $^{-1}$ & kcal day $^{-1}$ & SE & $n$ \\
\hline Males & $0-3$ & $0.255 \mathrm{~W}-0.141$ & $61.0 \mathrm{~W}-33.7$ & 0.255 & 277 \\
& $3-10$ & $0.0937 \mathrm{~W}+2.15$ & $23.3 \mathrm{~W}+514$ & 0.328 & 289 & 0.954 \\
& $10-18$ & $0.0769 \mathrm{~W}+2.43$ & $18.4 \mathrm{~W}+581$ & 0.566 & 863 & 0.861 \\
& $18-30$ & $0.0669 \mathrm{~W}+2.28$ & $16.0 \mathrm{~W}+545$ & 0.652 & 2821 & 0.760 \\
& $30-60$ & $0.0592 \mathrm{~W}+2.48$ & $14.2 \mathrm{~W}+593$ & 0.693 & 1010 & 0.742 \\
& $60+$ & $0.0563 \mathrm{~W}+2.15$ & $13.5 \mathrm{~W}+514$ & 0.685 & 534 & 0.776 \\
Females & $0-3$ & $0.246 \mathrm{~W}-0.0965$ & $58.9 \mathrm{~W}-23.1$ & 0.242 & 215 & 0.960 \\
& $3-10$ & $0.0842 \mathrm{~W}+2.12$ & $20.1 \mathrm{~W}+507$ & 0.360 & 403 & 0.820 \\
& $10-18$ & $0.0465 \mathrm{~W}+3.18$ & $11.1 \mathrm{~W}+761$ & 0.525 & 1063 & 0.752 \\
& $18-30$ & $0.0546 \mathrm{~W}+2.33$ & $13.1 \mathrm{~W}+558$ & 0.564 & 1664 & 0.700 \\
& $30-60$ & $0.0407 \mathrm{~W}+2.90$ & $9.74 \mathrm{~W}+694$ & 0.581 & 1023 & 0.690 \\
& $60+$ & $0.0424 \mathrm{~W}+2.38$ & $10.1 \mathrm{~W}+569$ & 0.485 & 334 & 0.786 \\
\hline
\end{tabular}

Abbreviation: BMR - basal metabolic rate. 
Basal metabolic rate studies in humans

Table 13 New Oxford equations with FAO/WHO/UNU equations for comparison

\begin{tabular}{lccc}
\hline Gender & Age $(\mathrm{y})$ & $\begin{array}{c}\text { BMR Oxford } \\
\left(\mathrm{MJ} \mathrm{day}^{-1}\right)\end{array}$ & BMR FAO $\left(\mathrm{MJ} \mathrm{day}^{-1}\right)$ \\
\hline Males & $0-3$ & $0.255 \mathrm{~W}-0.141$ & $0.255 \mathrm{~W}-0.226$ \\
& $3-10$ & $0.0937 \mathrm{~W}+2.15$ & $0.0949 \mathrm{~W}+2.07$ \\
& $10-18$ & $0.0769 \mathrm{~W}+2.43$ & $0.0732 \mathrm{~W}+2.72$ \\
& $18-30$ & $0.0669 \mathrm{~W}+2.28$ & $0.0640 \mathrm{~W}+2.84$ \\
& $30-60$ & $0.0592 \mathrm{~W}+2.48$ & $0.0485 \mathrm{~W}+3.67$ \\
Females & $60+$ & $0.0563 \mathrm{~W}+2.15$ & $0.0565 \mathrm{~W}+2.04$ \\
& $0-3$ & $0.246 \mathrm{~W}-0.0965$ & $0.255 \mathrm{~W}-0.214$ \\
& $3-10$ & $0.0842 \mathrm{~W}+2.12$ & $0.0941 \mathrm{~W}+2.09$ \\
& $10-18$ & $0.0465 \mathrm{~W}+3.18$ & $0.0510 \mathrm{~W}+3.12$ \\
& $18-30$ & $0.0546 \mathrm{~W}+2.33$ & $0.0615 \mathrm{~W}+2.08$ \\
& $30-60$ & $0.0407 \mathrm{~W}+2.90$ & $0.0364 \mathrm{~W}+3.47$ \\
& $60+$ & $0.0424 \mathrm{~W}+2.38$ & $0.0439 \mathrm{~W}+2.49$ \\
\hline
\end{tabular}

Abbreviations: FAO/WHO/UNU - Food and Agriculture Organization/World Health Organization/United Nations University; BMR - basal metabolic rate.

Table 14 Descriptive equations and statistics (mean \pm SD) of Oxford predictive equations for BMR in the elderly

\begin{tabular}{llccccc}
\hline Gender & Age $(\mathrm{y})$ & $\mathrm{MJ} \mathrm{day}^{-1}$ & $\mathrm{kcal} \mathrm{day}^{-1}$ & $\mathrm{SE}$ & $n$ & $r$ \\
\hline Males & $60-70$ & $0.0543 \mathrm{~W}+2.37$ & $13.0 \mathrm{~W}+567$ & 0.697 & 270 & 0.766 \\
& $70+$ & $0.0573 \mathrm{~W}+2.01$ & $13.7 \mathrm{~W}+481$ & 0.667 & 264 & 0.779 \\
Females & $60-70$ & $0.0429 \mathrm{~W}+2.39$ & $10.2 \mathrm{~W}+572$ & 0.476 & 185 & 0.798 \\
& $70+$ & $0.0417 \mathrm{~W}+2.41$ & $10.0 \mathrm{~W}+577$ & 0.518 & 155 & 0.746
\end{tabular}

Abbreviation: BMR - basal metabolic rate.

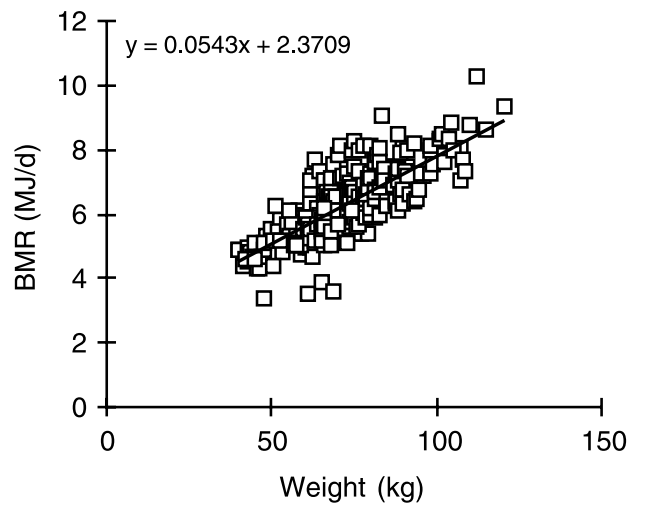

Fig. 5 Basal metabolic rate $(\mathrm{BMR})$ vs. body weight - males $60-70$ years

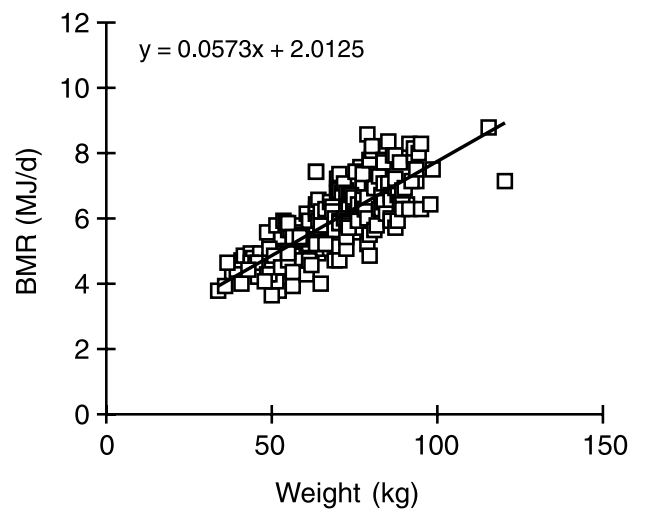

Fig. 6 Basal metabolic rate (BMR) vs. body weight - males 70+ years

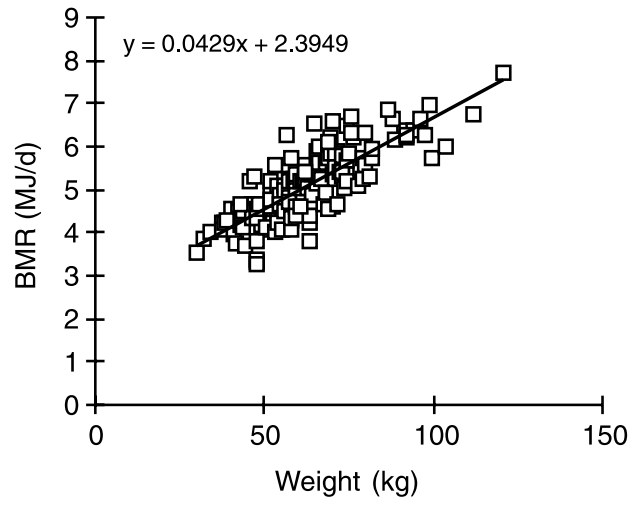

Fig. 7 Basal metabolic rate (BMR) vs. body weight - females $60-70$ years

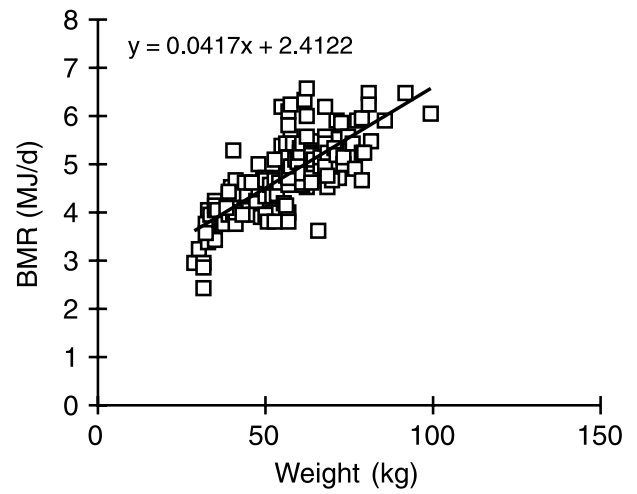

Fig. 8 Basal metabolic rate (BMR) vs. body weight - females $70+$ years

and $\mathrm{FAO} / \mathrm{WHO} / \mathrm{UNU}$ equations coincide with the ages at which a disproportionate number of Italian subjects were included in the Schofield database.

\section{Practical examples of how the use of Oxford BMR equations influence energy requirements}

On the basis of the new BMR equations, it is now possible to predict energy requirements in subjects performing different tasks.

Tables 21 and 22 predict total energy requirements at light, moderate and heavy physical activity levels in 18-30 year old males and females. It is apparent, when applying the Oxford equation for BMR, that a reduction in total energy requirements ranges from $396 \mathrm{~kJ}(95 \mathrm{kcal})$ to $841 \mathrm{~kJ}(201 \mathrm{kcal})$ per day for males, and $202 \mathrm{~kJ}$ ( $48 \mathrm{kcal})$ to $863 \mathrm{~kJ}$ (206 kcal) per day for females. As illustrative examples, Tables 23-28 show the effect an alteration in BMR will have on total energy requirements and cereal needs in various occupations. In the case of a subsistence farmer, moderately active, weighing $58 \mathrm{~kg}$, the reduction in energy needs per day turns out to be $676 \mathrm{~kJ}(162 \mathrm{kcal})$ and a reduction in cereal requirement of $41 \mathrm{~g} \mathrm{day}^{-1}$ or $15 \mathrm{~kg}$ per year. In the case of a 35 -year old male, engaged in heavy physical activity, weighing $65 \mathrm{~kg}$, the reduction in energy needs become $1064 \mathrm{~kJ}$ 
Table 15 Descriptive equations and statistics (mean $\pm \mathrm{SD}$ ) of Oxford prediction equations for BMR using height and weight

\begin{tabular}{lcccrrr}
\hline Gender & Age $(\mathrm{y})$ & \multicolumn{2}{c}{ MJ day $^{-1}$} & kcal day & SE & $n$ \\
\hline Males & $0-3$ & $0.118 \mathrm{~W}+3.59 \mathrm{H}-1.55$ & $28.2 \mathrm{~W}+859 \mathrm{H}-371$ & 0.246 & 246 & 0.959 \\
& $3-10$ & $0.0632 \mathrm{~W}+1.31 \mathrm{H}+1.28$ & $15.1 \mathrm{~W}+74.2 \mathrm{H}+306$ & 0.322 & 289 & 0.835 \\
& $10-18$ & $0.0651 \mathrm{~W}+1.11 \mathrm{H}+1.25$ & $15.6 \mathrm{~W}+266 \mathrm{H}+299$ & 0.562 & 863 & 0.864 \\
& $18-30$ & $0.060 \mathrm{~W}+1.31 \mathrm{H}+0.473$ & $14.4 \mathrm{~W}+313 \mathrm{H}+113$ & 0.648 & 2816 & 0.764 \\
& $30-60$ & $0.0476 \mathrm{~W}+2.26 \mathrm{H}-0.574$ & $11.4 \mathrm{~W}+541 \mathrm{H}-137$ & 0.678 & 1006 & 0.756 \\
& $60+$ & $0.0478 \mathrm{~W}+2.26 \mathrm{H}-1.07$ & $11.4 \mathrm{~W}+541 \mathrm{H}-256$ & 0.668 & 533 & 0.789 \\
Females & $0-3$ & $0.127 \mathrm{~W}+2.94 \mathrm{H}-1.20$ & $30.4 \mathrm{~W}+703 \mathrm{H}-287$ & 0.232 & 201 & 0.964 \\
& $3-10$ & $0.0666 \mathrm{~W}+0.878 \mathrm{H}+1.46$ & $15.9 \mathrm{~W}+210 \mathrm{H}+349$ & 0.357 & 403 & 0.825 \\
& $10-18$ & $0.0393 \mathrm{~W}+1.04 \mathrm{H}+1.93$ & $9.40 \mathrm{~W}+249 \mathrm{H}+462$ & 0.521 & 1063 & 0.758 \\
& $18-30$ & $0.0433 \mathrm{~W}+2.57 \mathrm{H}-1.18$ & $10.4 \mathrm{~W}+615 \mathrm{H}-282$ & 0.542 & 1655 & 0.724 \\
& $30-60$ & $0.0342 \mathrm{~W}+2.10 \mathrm{H}-0.0486$ & $8.18 \mathrm{~W}+502 \mathrm{H}-11.6$ & 0.564 & 1023 & 0.713 \\
& $60+$ & $0.0356 \mathrm{~W}+1.76 \mathrm{H}+0.0448$ & $8.52 \mathrm{~W}+421 \mathrm{H}+10.7$ & 0.472 & 324 & 0.805 \\
& & & & & &
\end{tabular}

Abbreviation: BMR - basal metabolic rate.

Table 16 Descriptive statistics (mean $\pm \mathrm{SD}$ ) of data in Oxford database

\begin{tabular}{crcccc}
\hline Gender & Age $(\mathrm{y})$ & Height $(\mathrm{m})$ & Weight $(\mathrm{kg})$ & BMI & ${\text { BMR }\left(\mathrm{MJ} \mathrm{day}^{-1}\right)}^{\text {M }}$ \\
\hline Males & & & & & \\
$0-3$ & $0.4 \pm 0.62$ & $0.65 \pm 0.13$ & $6.3 \pm 3.20$ & $15.1 \pm 2.01$ & $1.47 \pm 0.86$ \\
$3-10$ & $6.6 \pm 2.04$ & $1.17 \pm 0.13$ & $21.4 \pm 5.14$ & $15.5 \pm 1.26$ & $4.17 \pm 0.58$ \\
$10-18$ & $12.7 \pm 2.07$ & $1.49 \pm 0.15$ & $40.0 \pm 12.48$ & $17.7 \pm 2.65$ & $5.51 \pm 1.11$ \\
$18-30$ & $22.7 \pm 2.87$ & $1.70 \pm 0.09$ & $61.0 \pm 11.40$ & $20.9 \pm 2.84$ & $6.36 \pm 1.00$ \\
$30-60$ & $40.8 \pm 8.72$ & $1.69 \pm 0.09$ & $65.3 \pm 12.98$ & $22.8 \pm 3.24$ & $6.35 \pm 1.03$ \\
$60+$ & $70.9 \pm 7.60$ & $1.70 \pm 0.09$ & $71.3 \pm 14.94$ & $24.6 \pm 4.13$ & $6.17 \pm 1.09$ \\
Females & & & & & \\
$0-3$ & $0.5 \pm 0.71$ & $0.65 \pm 0.14$ & $6.7 \pm 3.40$ & $15.0 \pm 2.31$ & $1.54 \pm 0.87$ \\
$3-10$ & $7.1 \pm 1.77$ & $1.22 \pm 0.14$ & $23.6 \pm 6.14$ & $15.7 \pm 1.59$ & $4.10 \pm 0.63$ \\
$10-18$ & $13.0 \pm 2.35$ & $1.50 \pm 0.11$ & $43.4 \pm 12.91$ & $18.8 \pm 3.64$ & $5.20 \pm 0.80$ \\
$18-30$ & $22.4 \pm 3.01$ & $1.60 \pm 0.08$ & $53.2 \pm 10.04$ & $20.7 \pm 3.18$ & $5.24 \pm 0.79$ \\
$30-60$ & $41.6 \pm 8.18$ & $1.59 \pm 0.08$ & $59.1 \pm 13.65$ & $23.3 \pm 4.48$ & $5.31 \pm 0.80$ \\
$60+$ & $69.8 \pm 6.88$ & $1.56 \pm 0.09$ & $60.0 \pm 14.52$ & $24.3 \pm 4.78$ & $4.93 \pm 0.78$ \\
\end{tabular}

Abbreviations: BMI - body mass index; BMR - basal metabolic rate.

(254 kcal) per day with a reduction in cereal needs of approximately $65 \mathrm{~g}$. As a final comparison, the energy requirements of a rural woman in a developing country, weighing $50 \mathrm{~kg}$ are presented.

In summary, the Oxford equations produced lower $\mathrm{BMR}$ values than the $\mathrm{FAO} / \mathrm{WHO} / \mathrm{UNU}$ equations in the

Table 17 Prediction of BMR from weight and height or weight alone (mean $\pm \mathrm{SD})$

\begin{tabular}{|c|c|c|c|c|c|}
\hline \multirow[b]{2}{*}{ Gender } & \multirow[b]{2}{*}{ Age $(y)$} & \multicolumn{2}{|c|}{ BMR $\left(\right.$ MJ day $\left.^{-1}\right)$} & \multirow{2}{*}{$\begin{array}{c}\% \\
\text { difference }\end{array}$} & \multirow[b]{2}{*}{$P$} \\
\hline & & Weight alone & Weight + height & & \\
\hline \multirow[t]{6}{*}{ Males } & $0-3$ & $1.474 \pm 0.86$ & $1.564 \pm 0.82$ & -6.12 & 0.169 \\
\hline & & 4.168 & 4.16 & -0.02 & 0.465 \\
\hline & $10-18$ & $5.506 \pm$ & 5.50 & +0.01 & 0.767 \\
\hline & $18-30$ & $6.364 \pm 1.00$ & 0.77 & -0.02 & 0.3 \\
\hline & $30-60$ & $6.347 \pm 1.03$ & $6.349 \pm 0.78$ & -0.01 & 0.808 \\
\hline & $60+$ & $6.173 \pm 1.09$ & $6.178 \pm 0.86$ & -0.08 & 0.615 \\
\hline \multirow[t]{6}{*}{ Females } & $0-3$ & $1.544 \pm 0.87$ & $1.598 \pm 0.84$ & -3.56 & 0.245 \\
\hline & $3-10$ & $4.100 \pm 0.63$ & $4.096 \pm 0.52$ & 0.12 & 0.617 \\
\hline & $10-18$ & $5.202 \pm 0.80$ & $5.199 \pm 0.60$ & 0.05 & 0.995 \\
\hline & $18-30$ & $5.239 \pm 0.79$ & $5.232 \pm 0.57$ & +0.14 & 0.800 \\
\hline & $30-60$ & $5.306 \pm 0.80$ & $5.307 \pm 0.57$ & -0.02 & 0.658 \\
\hline & $60+$ & $4.931 \pm 0.78$ & $4.934 \pm 0.64$ & -0.05 & 0.640 \\
\hline
\end{tabular}

Abbreviation: BMR - basal metabolic rate.
18-30 and 30-60 year old males and in all females over 18 years of age. In the examples cited above (where the newly calculated BMR was used to estimated energy requirements), the Oxford BMR equation produced a significant reduction in total energy and cereal requirements per day. Possible explanations for these differences in BMR when applying the Oxford equations may be because the Oxford database (1) did not include any of the elevated BMR values of the Italian subjects and (2) included a much larger number of people from the tropical region (see Table 29).

\section{Discussion and areas for future research}

One practical use of BMR is in the estimation of energy requirements for population groups and subsequently their food needs. The FAO/WHO/UNU report Energy and Protein Requirements ${ }^{1}$ made clear for the first time two main purposes of determining energy requirements. The first was for prescriptive purposes, i.e. for making recommendations about the level of consumption that ought to be maintained in a population; the second, for diagnostic purposes, i.e. the assessment of the 
Table 18 Comparison of Oxford and FAO/WHO/UNU BMR equations in males at various ages ( $\left.\mathrm{MJ} \mathrm{day}^{-1}\right)$

\begin{tabular}{|c|c|c|c|c|}
\hline Age & Weight (kg) & BMR $(O x)$ & BMR (FAO) & $\begin{array}{c}\text { Difference } \\
\text { from FAO }(\%)^{a}\end{array}$ \\
\hline \multirow[t]{7}{*}{$0-3$} & 3 & 0.624 & 0.5390 & -15.77 \\
\hline & 5 & 1.134 & 1.0490 & -8.10 \\
\hline & 10 & 2.409 & 2.3240 & -3.66 \\
\hline & 12 & 2.919 & 2.8340 & -3.00 \\
\hline & 15 & 3.684 & 3.5990 & -2.36 \\
\hline & 18 & 4.449 & 4.3640 & -1.95 \\
\hline & 20 & 4.959 & 4.8740 & -1.74 \\
\hline \multirow[t]{9}{*}{$3-10$} & 12 & 3.2744 & 3.2088 & -2.04 \\
\hline & 15 & 3.5555 & 3.4935 & -1.77 \\
\hline & 18 & 3.8366 & 3.7782 & -1.55 \\
\hline & 22 & 4.2114 & 4.1578 & -1.29 \\
\hline & 25 & 4.4925 & 4.4425 & -1.13 \\
\hline & 30 & 4.961 & 4.9170 & -0.89 \\
\hline & 35 & 5.4295 & 5.3915 & -0.70 \\
\hline & 45 & 6.3665 & 6.3405 & -0.41 \\
\hline & 50 & 6.835 & 6.8150 & -0.29 \\
\hline \multirow[t]{9}{*}{$10-18$} & 25 & 4.3525 & 4.5500 & +4.34 \\
\hline & 30 & 4.737 & 4.9160 & +3.64 \\
\hline & 35 & 5.1215 & 5.2820 & +3.04 \\
\hline & 45 & 5.8905 & 6.0140 & +2.05 \\
\hline & 55 & 6.6595 & 6.7460 & +1.28 \\
\hline & 65 & 7.4285 & 7.4780 & +0.66 \\
\hline & 75 & 8.1975 & 8.2100 & +0.15 \\
\hline & 95 & 9.7355 & 9.6740 & -0.64 \\
\hline & 105 & 10.5045 & 10.4060 & -0.95 \\
\hline \multirow{8}{*}{$18-30$} & 50 & 5.6250 & 6.0400 & +6.87 \\
\hline & 55 & 5.9595 & 6.3600 & +6.30 \\
\hline & 60 & 6.294 & 6.6800 & +5.78 \\
\hline & 65 & 6.6285 & 7.0000 & +5.31 \\
\hline & 75 & 7.2975 & 7.6400 & +4.48 \\
\hline & 85 & 7.9665 & 8.2800 & +3.79 \\
\hline & 95 & 8.6355 & 8.9200 & +3.19 \\
\hline & 105 & 9.3045 & 9.5600 & +2.67 \\
\hline \multirow[t]{8}{*}{$30-60$} & 50 & 5.440 & 6.0950 & +10.75 \\
\hline & 55 & 5.736 & 6.3375 & +9.49 \\
\hline & 60 & 6.032 & 6.5800 & +8.33 \\
\hline & 65 & 6.328 & 6.8225 & +7.25 \\
\hline & 75 & 6.92 & 7.3075 & +5.30 \\
\hline & 85 & 7.512 & 7.7925 & +3.60 \\
\hline & 95 & 8.104 & 8.2775 & +2.10 \\
\hline & 105 & 8.696 & 8.7625 & +0.76 \\
\hline \multirow[t]{7}{*}{$60+$} & 55 & 5.2465 & 5.1475 & -1.92 \\
\hline & 60 & 5.528 & 5.4300 & -1.80 \\
\hline & 65 & 5.8095 & 5.7125 & -1.70 \\
\hline & 75 & 6.3725 & 6.2775 & -1.51 \\
\hline & 85 & 6.9355 & 6.8425 & -1.36 \\
\hline & 95 & 7.4985 & 7.4075 & -1.23 \\
\hline & 100 & 7.78 & 7.6900 & -1.17 \\
\hline
\end{tabular}

Abbreviations: FAO/WHO/UNU - Food and Agriculture Organization/World Health Organization/United Nations University; BMR - basal metabolic rate.

${ }^{a}+$ indicates that FAOs formulae give higher values, and - indicates lower values.

adequacy or otherwise of the food needs in a population. In the factorial estimation of total energy expenditure $(\mathrm{FAO} / \mathrm{WHO} / \mathrm{UNU})^{1}$, a major feature and component was the estimation of BMR. The measurement and prediction of BMR thus took on a greater significance. It is important to recognise that the primary purpose of the early measures of BMR (1900-1950) was to diagnose hypo- or hyperthyroidism, not to estimate energy requirements.
Table 19 Comparison of Oxford and FAO/WHO/UNU BMR equations in females at various ages $\left(\mathrm{MJ}_{\text {day }}{ }^{-1}\right)$

\begin{tabular}{|c|c|c|c|c|}
\hline Age & Weight (kg) & BMR (Ox) & BMR (FAO) & $\begin{array}{l}\text { Difference from } \\
\text { FAO }(\%)^{\mathrm{a}}\end{array}$ \\
\hline \multirow[t]{7}{*}{$0-3$} & 3 & 0.6415 & 0.5510 & -16.42 \\
\hline & 5 & 1.1335 & 1.0610 & -6.83 \\
\hline & 10 & 2.3635 & 2.3360 & -1.18 \\
\hline & 12 & 2.8555 & 2.8460 & -0.33 \\
\hline & 15 & 3.5935 & 3.6110 & +0.48 \\
\hline & 18 & 4.3315 & 4.3760 & +1.02 \\
\hline & 20 & 4.8235 & 4.8860 & +1.28 \\
\hline \multirow[t]{9}{*}{$3-10$} & 12 & 3.1304 & 3.2192 & +2.76 \\
\hline & 15 & 3.383 & 3.5015 & +3.38 \\
\hline & 18 & 3.6356 & 3.7838 & +3.92 \\
\hline & 22 & 3.9724 & 4.1602 & +4.51 \\
\hline & 25 & 4.225 & 4.4425 & $\begin{array}{r}+4.90 \\
\end{array}$ \\
\hline & 30 & 4.646 & 4.9130 & +5.43 \\
\hline & 35 & 5.067 & 5.3835 & +5.88 \\
\hline & 45 & 5.909 & 6.3245 & +6.57 \\
\hline & 50 & 6.33 & 6.7950 & +6.84 \\
\hline \multirow[t]{9}{*}{$10-18$} & 25 & 4.3425 & 4.3950 & +1.19 \\
\hline & 30 & 4.575 & 4.6500 & +1.61 \\
\hline & 35 & 4.8075 & 4.9050 & +1.99 \\
\hline & 45 & 5.2725 & 5.4150 & +2.63 \\
\hline & 55 & 5.7375 & 5.9250 & +3.16 \\
\hline & 65 & 6.2025 & 6.4350 & +3.61 \\
\hline & 75 & 6.6675 & 6.9450 & +4.00 \\
\hline & 95 & 7.5975 & 7.9650 & +4.61 \\
\hline & 105 & 8.0625 & 8.4750 & +4.87 \\
\hline \multirow[t]{8}{*}{$18-30$} & 50 & 5.060 & 5.1550 & +1.84 \\
\hline & 55 & 5.333 & 5.4625 & +2.37 \\
\hline & 60 & 5.606 & 5.7700 & +2.84 \\
\hline & 65 & 5.879 & 6.0775 & +3.27 \\
\hline & 75 & 6.425 & 6.6925 & +4.00 \\
\hline & 85 & 6.971 & 7.3075 & +4.60 \\
\hline & 95 & 7.517 & 7.9225 & +5.12 \\
\hline & 105 & 8.063 & 8.5375 & +5.56 \\
\hline \multirow[t]{8}{*}{$30-60$} & 50 & 4.935 & 5.2900 & $\begin{array}{r}6.71 \\
+6.71\end{array}$ \\
\hline & 55 & 5.1385 & 5.4720 & +6.09 \\
\hline & 60 & 5.342 & 5.6540 & $\begin{array}{r}+5.52 \\
\end{array}$ \\
\hline & 65 & 5.5455 & 5.8360 & +4.98 \\
\hline & 75 & 5.9525 & 6.2000 & +3.99 \\
\hline & 85 & 6.3595 & 6.5640 & +3.12 \\
\hline & 95 & 6.7665 & 6.9280 & +2.33 \\
\hline & 105 & 7.1735 & 7.2920 & +1.63 \\
\hline \multirow[t]{7}{*}{$60+$} & 55 & 4.712 & 4.9045 & +3.92 \\
\hline & 60 & 4.924 & 5.1240 & +3.90 \\
\hline & 65 & 5.136 & 5.3435 & +3.88 \\
\hline & 75 & 5.56 & 5.7825 & +3.85 \\
\hline & 85 & 5.984 & 6.2215 & +3.82 \\
\hline & 95 & 6.408 & 6.6605 & +3.79 \\
\hline & 100 & 6.62 & 6.8800 & +3.78 \\
\hline
\end{tabular}

Abbreviations: FAO/WHO/UNU - Food and Agriculture Organization/World Health Organization/United Nations University; BMR - basal metabolic rate.

${ }^{a}+$ indicates that FAOs formulae give higher values, and - indicates lower values.

The Schofield database comprised 114 published studies of BMR, totalling 7173 data points. These formed the basis for the equations used in the FAO/WHO/UNU document Energy and Protein Requirements ${ }^{1}$. While Schofield's analysis has served a significant role in re-establishing the importance of using BMR to predict human energy requirements, recent workers have subsequently queried the universal validity and application of these equations. A survey of the most recent 
Table 20 Summary of difference between the Oxford and FAO equations

\begin{tabular}{|c|c|c|c|}
\hline $\begin{array}{l}\text { Sex and age band } \\
\text { (male/female, years) }\end{array}$ & $\begin{array}{l}\text { Oxford equation } \\
\left(\mathrm{MJ} \mathrm{day}^{-1}\right)\end{array}$ & $\begin{array}{l}\text { Schofield (1985) equation } \\
\left(\mathrm{MJ} \mathrm{day}^{-1}\right)\end{array}$ & Difference \\
\hline Males, $0-3$ & $0.225 W-0.141$ & $0.255 W-0.226$ & Large difference at low body weights \\
\hline Females, 0-3 & $0.246 W-0.0965$ & $0.255 W-0.214$ & Large difference at low body weights \\
\hline Males, $3-10$ & $0.0937 \mathrm{~W}+2.15$ & $0.0949 W+2.07$ & No significant difference \\
\hline Females, 3-10 & $0.0842 W+2.12$ & $0.0941 W+2.09$ & Difference at high body weights \\
\hline Males, $10-18$ & $0.0769 W+2.43$ & $0.0732 W+2.72$ & Difference at low body weights \\
\hline Females, $10-18$ & $0.0465 W+3.18$ & $0.0510 W+3.12$ & Difference at high body weights \\
\hline Males, $18-30$ & $0.0669 W+2.28$ & $0.0640 W+284$ & Large difference at body weight $<75 \mathrm{~kg}$ \\
\hline Females, $18-30$ & $0.0546 W+2.33$ & $0.0615 W+2.08$ & Large difference at body weight $<75 \mathrm{~kg}$ \\
\hline Males, $30-60$ & $0.0592 W+2.48$ & $0.0485 W+3.67$ & Very large difference at body weight $<75 \mathrm{~kg}$ \\
\hline Females, $30-60$ & $0.0407 \mathrm{~W}+2.90$ & $0.0364 W+3.47$ & Large difference at body weight $<65 \mathrm{~kg}$ \\
\hline Males, $60+$ & $0.0563 W+2.15$ & $0.0565 W+2.04$ & No significant difference \\
\hline Females, $60+$ & $0.0424 W+2.38$ & $0.0439 W+2.49$ & Difference across body weights \\
\hline
\end{tabular}

Abbreviation: FAO - Food and Agriculture Organization.

studies (1980-2000) in BMR suggests that in most cases the current $\mathrm{FAO} / \mathrm{WHO} / \mathrm{UNU}$ predictive equations overestimate BMR in many communities.

It is concluded that the over-representation of BMR values obtained from Italian subjects - 3388 out of 7173 (who had a higher BMR kg ${ }^{-1}$ ) in the Schofield ${ }^{1}$ database may have resulted in the $\mathrm{FAO} / \mathrm{WHO} / \mathrm{UNU}$ predictive equations to overestimate BMR in contemporary populations.

A series of new equations (Oxford equations) have been developed using a data set of 10552 BMR values that (1) excluded all the Italian subjects and (2) included a much

Table 21 Differences in total EE for light, moderate and high activity levels in males (18-30 years) using Oxford and $\mathrm{FAO} / \mathrm{WHO} / \mathrm{UNU}$ equations (MJ day $^{-1}$ )

\begin{tabular}{|c|c|c|c|c|c|}
\hline Weight & $\begin{array}{l}\text { BMR } \\
(\mathrm{Ox})\end{array}$ & $\begin{array}{l}\text { BMR } \\
\text { (FAO) }\end{array}$ & $\begin{array}{l}E E \\
(O x)\end{array}$ & $\begin{array}{c}\mathrm{EE} \\
(\mathrm{FAO})\end{array}$ & $\begin{array}{c}\text { Difference } \\
\text { from FAO }(k J)\end{array}$ \\
\hline \multicolumn{6}{|c|}{ Light Activity (1.55) } \\
\hline 55 & 5.9595 & 6.3600 & 9.237225 & 9.858 & -620.77 \\
\hline 60 & 6.2940 & 6.6800 & 9.7557 & 10.354 & -598.30 \\
\hline 65 & 6.6285 & 7.0000 & 10.27418 & 10.85 & -575.82 \\
\hline 75 & 7.2975 & 7.6400 & 11.31113 & 11.842 & -530.88 \\
\hline 85 & 7.9665 & 8.2800 & 12.34808 & 12.834 & -485.93 \\
\hline 95 & 8.6355 & 8.9200 & 13.38503 & 13.826 & -440.98 \\
\hline 105 & 9.3045 & 9.5600 & 14.42198 & 14.818 & -396.02 \\
\hline \multicolumn{6}{|c|}{ Moderate Activity (1.76) } \\
\hline 55 & 5.9595 & 6.3600 & 10.48872 & 11.1936 & -704.88 \\
\hline 60 & 6.2940 & 6.6800 & 11.07744 & 11.7568 & -679.36 \\
\hline 65 & 6.6285 & 7.0000 & 11.66616 & 12.32 & -653.84 \\
\hline 75 & 7.2975 & 7.6400 & 12.8436 & 13.4464 & -602.80 \\
\hline 85 & 7.9665 & 8.2800 & 14.02104 & 14.5728 & -551.76 \\
\hline 95 & 8.6355 & 8.9200 & 15.19848 & 15.6992 & -500.72 \\
\hline 105 & 9.3045 & 9.5600 & 16.37592 & 16.8256 & -449.68 \\
\hline \multicolumn{6}{|c|}{ High Activity (2.10) } \\
\hline 55 & 5.9595 & 6.3600 & 12.51495 & 13.356 & -841.05 \\
\hline 60 & 6.2940 & 6.6800 & 13.2174 & 14.028 & -810.60 \\
\hline 65 & 6.6285 & 7.0000 & 13.91985 & 14.7 & -780.15 \\
\hline 75 & 7.2975 & 7.6400 & 15.32475 & 16.044 & -719.25 \\
\hline 85 & 7.9665 & 8.2800 & 16.72965 & 17.388 & -658.35 \\
\hline 95 & 8.6355 & 8.9200 & 18.13455 & 18.732 & -597.45 \\
\hline 105 & 9.3045 & 9.5600 & 19.53945 & 20.076 & -536.55 \\
\hline
\end{tabular}

Abbreviations: EE - energy expenditure; FAO/WHO/UNU - Food and Agriculture Organization/World Health Organization/United Nations University; BMR - basal metabolic rate. larger number (4018) of people from the tropics. In general, the Oxford equations tend to produce lower BMR values than the current $\mathrm{FAO} / \mathrm{WHO} / \mathrm{UNU}$ equations in 18-30 and $30-60$ year old males and in all females over 18 years of age (see pages 33-42 for detailed discussion). The objective of all consultations is to scientifically progress and identify fresh ideas and issues. This is an opportune moment to reexamine the role and place of BMR measurements in estimating total energy requirements today. The Oxford equations use and future application will surely depend on their ability to predict more accurately the BMR in contemporary populations.

Table 22 Differences in total EE for light, moderate and high activity levels in females (18-30 years) using Oxford and $\mathrm{FAO} / \mathrm{WHO} / \mathrm{UNU}$ equations (MJ day $^{-1}$ )

\begin{tabular}{lccrcc}
\hline Weight & $\begin{array}{c}\text { BMR } \\
(\mathrm{Ox})\end{array}$ & $\begin{array}{c}\text { BMR } \\
(\mathrm{FAO})\end{array}$ & $\begin{array}{c}\mathrm{EE} \\
(\mathrm{Ox})\end{array}$ & $\begin{array}{c}\text { EE } \\
(\mathrm{FAO})\end{array}$ & $\begin{array}{c}\text { Difference } \\
\text { from FAO (kJ) }\end{array}$ \\
\hline \multicolumn{2}{l}{ Light activity $(1.56)$} & & & & \\
55 & 5.3330 & 5.4625 & 8.32 & 8.5215 & -202.02 \\
60 & 5.6060 & 5.7700 & 8.75 & 9.0012 & -255.84 \\
65 & 5.8790 & 6.0775 & 9.17 & 9.4809 & -309.66 \\
75 & 6.4250 & 6.6925 & 10.02 & 10.4403 & -417.3 \\
85 & 6.9710 & 7.3075 & 10.87 & 11.3997 & -524.94 \\
95 & 7.5170 & 7.9225 & 11.73 & 12.3591 & -632.58 \\
105 & 8.0630 & 8.5375 & 12.58 & 13.3185 & -740.22 \\
Moderate & activity & $(1.64)$ & & & \\
55 & 5.3330 & 5.4625 & 8.75 & 8.9585 & -212.38 \\
60 & 5.6060 & 5.7700 & 9.19 & 9.4628 & -268.96 \\
65 & 5.8790 & 6.0775 & 9.64 & 9.9671 & -325.54 \\
75 & 6.4250 & 6.6925 & 10.54 & 10.9757 & -438.7 \\
85 & 6.9710 & 7.3075 & 11.43 & 11.9843 & -551.86 \\
95 & 7.5170 & 7.9225 & 12.33 & 12.9929 & -665.02 \\
105 & 8.0630 & 8.5375 & 13.22 & 14.0015 & -778.18 \\
High activity $(1.82)$ & & & & \\
55 & 5.3330 & 5.4625 & 9.71 & 9.94175 & -235.69 \\
60 & 5.6060 & 5.7700 & 10.20 & 10.5014 & -298.48 \\
65 & 5.8790 & 6.0775 & 10.70 & 11.06105 & -361.27 \\
75 & 6.4250 & 6.6925 & 11.69 & 12.18035 & -486.85 \\
85 & 6.9710 & 7.3075 & 12.69 & 13.29965 & -612.43 \\
95 & 7.5170 & 7.9225 & 13.68 & 14.41895 & -738.01 \\
105 & 8.0630 & 8.5375 & 14.67 & 15.53825 & -863.59 \\
\hline
\end{tabular}

Abbreviations: EE - energy expenditure; FAO/WHO/UNU - Food and Agriculture Organization/World Health Organization/United Nations University; BMR - basal metabolic rate. 
Table 23 Energy requirement of a subsistence farmer (moderate activity work) using FAO/WHO/UNU equations (age: 25 years, weight: $58 \mathrm{~kg}$, height: $1.61 \mathrm{~m}$, BMI: 22.4)

\begin{tabular}{lrrr}
\hline & Hours & $\mathrm{kcal}_{\text {th }}$ & $\mathrm{kJ}$ \\
\hline In bed at 1.0 $\times$ BMR & 8 & 520 & 2170 \\
Occupational activities at 2.7 $\times$ BMR & 7 & 1230 & 5150 \\
Discretionary activities: & & & \\
$\quad$-Socially desirable and household tasks at 3.0 $\times$ BMR & 2 & 390 & 1630 \\
$\quad-$ Cardiovascular and muscular maintenance-not needed if moderately active & - & & \\
For residual time, energy needs at 1.4 $\times$ BMR & 7 & 640 & 2680 \\
Total = $1.78 \times$ BMR & & 2780 & 11630
\end{tabular}

Abbreviations: FAO/WHO/UNU - Food and Agriculture Organization/World Health Organization/United Nations University; BMI - body mass index; BMR - basal metabolic rate.

Source: FAO/WHO/UNU'.

Estimated BMR: $65 \mathrm{kcal}_{\mathrm{th}}(273 \mathrm{~kJ}) / \mathrm{h}$.

Table 24 Energy requirement of a subsistence farmer (moderate activity work) using Oxford equations (age: 25 years, weight: $58 \mathrm{~kg}$, height: $1.61 \mathrm{~m}$, BMl: 22.4)

\begin{tabular}{|c|c|c|c|}
\hline & Hours & $\mathrm{kcal}_{\text {th }}$ & $\mathrm{kJ}$ \\
\hline In bed at $1.0 \times \mathrm{BMR}$ & 8 & 491 & 2052 \\
\hline Occupational activities at $2.7 \times$ BMR & 7 & 1160 & 4849 \\
\hline Discretionary activities: & & & \\
\hline $\begin{array}{l}\text { - Socially desirable and household tasks at } 3.0 \times \text { BMR } \\
\text {-Cardiovascular and muscular maintenance }- \text { not needed if moderately active }\end{array}$ & 2 & 368 & 1539 \\
\hline $\begin{array}{l}\text { For residual time, energy needs at } 1.4 \times \text { BMR } \\
\text { Total }=1.78 \times \text { BMR }\end{array}$ & 7 & $\begin{array}{r}601 \\
2621\end{array}$ & $\begin{array}{r}2514 \\
10954\end{array}$ \\
\hline
\end{tabular}

Abbreviations: BMI - body mass index; BMR - basal metabolic rate.

Reduction in energy requirements per day $=676 \mathrm{~kJ}$ (162 kcal).

Reduction in cereal requirements per day $=41 \mathrm{~g}$ (assuming energy value of $16.3 \mathrm{~kJ} \mathrm{~g}^{-1}$ - raw rice (McCance and Widdowson $\left.{ }^{94}\right)$ )

Reduction in cereal requirements per year $=15.0 \mathrm{~kg}$

Estimated BMR: $61.5 \mathrm{kcal}_{\text {th }}(257 \mathrm{~kJ})$ per hour.

Table 25 Energy requirement for a male engaged in heavy work using the Oxford equations (age: 35 years, weight: $65 \mathrm{~kg}$, height: $1.72 \mathrm{~m}, \mathrm{BMI}: 22$ )

\begin{tabular}{lrrr}
\hline & Hours & $\mathrm{kcal}_{\mathrm{th}}$ & $\mathrm{kJ}$ \\
\hline In bed at $1.0 \times$ BMR & 8 & 545 & 2280 \\
Occupational activities at $3.8 \times$ BMR & 8 & 2070 & 8660 \\
Discretionary activities at $3.0 \times$ BMR & 1 & 205 & 860 \\
For residual time, maintenance energy needs & 7 & 670 & 2800 \\
$\quad$ at $1.4 \times$ BMR & & & \\
Total $=2.14 \times$ BMR & & 3490 & 14580
\end{tabular}

Abbreviations: BMI - body mass index; BMR - basal metabolic rate. Source: $\mathrm{FAO} / \mathrm{WHO} / \mathrm{UNU}^{1}$

Estimated BMI: $68 \mathrm{kcal}_{\text {th }}(284 \mathrm{~kJ})$ per hour.

Table 26 Energy requirement for a male engaged in heavy work using the Oxford equations (age 35 years, weight $65 \mathrm{~kg}$, height $1.72 \mathrm{~m}, \mathrm{BMI} 22$ )

\begin{tabular}{lrrr}
\hline & Hours & $\mathrm{kcal}_{\mathrm{th}}$ & $\mathrm{kJ}$ \\
\hline In bed at 1.0 $\times$ BMR & 8 & 505 & 2112 \\
Occupational activities at 3.8 $\times$ BMR & 8 & 1920 & 8025 \\
Discretionary activities at 3.0 $\times$ BMR & 1 & 189 & 792 \\
For residual time, maintenance energy needs & 7 & 619 & 2587 \\
$\quad$ at $1.4 \times$ BMR & & & \\
Total $=2.14 \times$ BMR & & 3233 & 13516 \\
\hline
\end{tabular}

Abbreviations: BMI - body mass index; BMR - basal metabolic rate. Reduction in energy requirements per day $=1064 \mathrm{~kJ}(254 \mathrm{kcal})$.

Reduction in cereal requirements per day $=65 \mathrm{~g}$ (assuming energy value of $16.3 \mathrm{~kJ} \mathrm{~g}^{-1}$ - raw rice (McCance and Widdowson ${ }^{94}$ ).

Reduction in cereal requirements per year $=23.7 \mathrm{~kg}$.

Estimated BMR: $63 \mathrm{kcal}_{\text {th }}(264 \mathrm{~kJ})$ per hour.

\section{Areas for further research}

1. It is recommended that a more detailed analysis of BMR in children aged between 10 and 18 years and from different communities be undertaken. A break down of the age band into more physiologically acceptable ranges, e.g. $10-12,12-15$ and $15-18$ years, is recommended.

2. There is an urgent need to develop age and gender specific BMR equations taking into account the stages in pubertal development (Tanner rating). Because of the rapid changes during puberty (changes in body composition, hormone levels, growth), even small age differences may cause large changes in metabolic rate.

3. There is a glaring absence of BMR data from mainland China and Africa. It is recommended that BMR values are collected from China and other developing countries, especially from young children and the elderly.

4. While BMR data collection in the elderly living in developing countries should be encouraged, the present age band for the elderly should be further refined to the following groups: $60-75,76-85$ and $>85$ years. 
Table 27 Energy requirement of a rural woman in a developing country using $\mathrm{FAO} / \mathrm{WHO} / \mathrm{UNU}$ equations (age: 35 years, weight: $50 \mathrm{~kg}$, height: $1.6 \mathrm{~m}$, BMI: 19.5)

\begin{tabular}{|c|c|c|c|}
\hline & Hours & $\mathrm{kcal}_{\mathrm{th}}$ & $\mathrm{KJ}$ \\
\hline In bed at $1.0 \times$ BMR & 8 & 425 & 1780 \\
\hline Occupational activities: & & & \\
\hline $\begin{array}{l}\text { - Housework, preparing food, etc, } \\
\text { at } 2.7 \times \text { BMR }\end{array}$ & 3 & 430 & 1800 \\
\hline -Working in fields, at $2.8 \times \mathrm{BMR}$ & 4 & 595 & 2490 \\
\hline Discretionary activities at $2.5 \times$ BMR & 2 & 265 & 1110 \\
\hline $\begin{array}{l}\text { For residual time, energy needs } \\
\text { at } 1.4 \times \mathrm{BMR}\end{array}$ & 7 & 520 & 2180 \\
\hline Total $=1.76 \times$ BMR & & 2235 & 9360 \\
\hline
\end{tabular}

Abbreviations: FAO/WHO/UNU - Food and Agriculture Organization/World Health Organization/United Nations University; BMI - body mass index; BMR - basal metabolic rate.

Source: $\mathrm{FAO} / \mathrm{WHO} / \mathrm{UNU}^{1}$

Estimated BMR: $53 \mathrm{kcal}_{\text {th }}(220 \mathrm{~kJ})$ per hour.

Table 28 Energy requirement of a rural woman in a developing country using Oxford equations (age: 35 years, weight: $50 \mathrm{~kg}$ height: $1.6 \mathrm{~m}$, BMl: 19.5)

\begin{tabular}{lccc}
\hline & Hours & $\mathrm{kcal}_{\text {th }}$ & $\mathrm{KJ}$ \\
\hline In bed at 1.0 $\times$ BMR & 8 & 392 & 1640 \\
Occupational activities: & & & \\
$\quad$ - Housework, preparing food, etc, & 3 & 397 & 1660 \\
$\quad$ at $2.7 \times$ BMR & & & \\
$\quad$-Working in fields, at 2.8 $\times$ BMR & 4 & 549 & 2296 \\
Discretionary activities at 2.5 $\times$ BMR & 2 & 245 & 1025 \\
For residual time, energy needs & 7 & 480 & 2009 \\
$\quad$ at $1.4 \times$ BMR & & & \\
$\quad$ Total $=1.76 \times$ BMR & & 2063 & 8630 \\
\hline
\end{tabular}

Abbreviations: BMI - body mass index; BMR - basal metabolic rate. Reduction in energy requirements per day $=730 \mathrm{~kJ}(175 \mathrm{kcal})$.

Reduction in cereal requirements per day $=45 \mathrm{~g}$ (assuming energy value of $16.3 \mathrm{~kJ} \mathrm{~g}^{-1}$ - raw rice (McCance and Widdowson ${ }^{94}$ )

Reduction in cereal requirements per year $=16.4 \mathrm{~kg}$

Estimated BMR: $49 \mathrm{kcal}_{\text {th }}(206 \mathrm{~kJ})$ per hour.

Table 29 Comparison between Oxford database and Schofield database

\begin{tabular}{lccc}
\hline & $\begin{array}{c}\text { Number } \\
\text { of papers }\end{array}$ & $\begin{array}{c}\text { Number of } \\
\text { data points }\end{array}$ & $\%$ \\
\hline Oxford database & 166 & 10552 & \\
$\begin{array}{l}\text { Common to Schofield and } \\
\text { Oxford database }\end{array}$ & 77 & 4039 & \\
$\begin{array}{l}\text { New in Oxford database } \\
\text { Tropical subjects in }\end{array}$ & 89 & 6513 & \\
$\quad \begin{array}{l}\text { Schofield database } \\
\text { Percentage of tropical subjects } \\
\text { in Schofield database }\end{array}$ & & 937 & \\
$\begin{array}{l}\text { Tropical subjects in Oxford } \\
\text { database }\end{array}$ & & 13 \\
$\begin{array}{l}\text { Percentage of tropical subjects } \\
\text { in Oxford database }\end{array}$ & & & \\
\hline
\end{tabular}

\section{Acknowledgements}

The author wishes to thank IDECG Switzerland, Nestle Foundation and FAO Rome, for supporting this analysis. The efforts of David Martineau, Darren Massey and
Helen Lightowler are also gratefully acknowledged. Special thanks to Drs. Butte, Chen, Goldberg, Jones, Muhilal, Poehlman, Pullicino, Reilly, Soares, Shetty, Westerterp and Wong for sending their raw data on BMR so readily.

\section{References}

1 FAO/WHO/UNU. Energy and Protein Requirements. Report of a Joint FAO/WHO/UNU Expert Consultation. Technical Report Series No. 724. Geneva: World Health Organization, 1985.

2 Mitchell HH. Comparative Nutrition of Man and Domestic Animals. Vol. I. New York: Academic Press, 1964.

3 Aub JC, DuBois EF. Clinical calorimetry: the basal metabolism of dwarfs and legless men with observations on the specific dynamic action of protein. Archives of Internal Medicine 1917; 19: 840-64.

4 Aub JC, DuBois EF. The basal metabolism of old men. Archives of Internal Medicine 1917; 19: 823-31.

5 Krogh A. Determination of standard (basal) metabolism of patients by recording apparatus. Boston Medical Surgery Journal 1923; 189: 313-7.

6 Blaxter K. Energy Metabolism in Animals and Man. Cambridge: Cambridge University Press, 1989.

7 DuBois EF, Ebaugh FG, Hardy JD. Basal heat production and elimination of thirteen normal women at temperatures from $22-35^{\circ} \mathrm{C}$. Journal of Nutrition 1952; 48: 257-93.

8 Wilkerson JE, Raven PB, Horvath SM. Critical temperature of unacclimatized male Caucasians. Journal of Applied Physiology 1972; 33: 451-5.

9 Pi-Suner J. Studies in racial metabolism: basal metabolism of the Araucanian Mapuches. American Journal of Physiology 1933; 105: 383-8.

10 Roth P, Buckingham PE. The criteria of a dependable basal metabolism report. American Journal of Clinical Pathology 1939; 9: 79-92.

11 Harris JA, Benedict FG. A Biometric Study of Basal Metabolism in Man. Publication No. 279. Washington: Carnegie Institute of Washington, 1919

12 Bedale EM. Energy expenditure and food requirements of children at school. Proceedings of the Royal Society of London 1923; 94: 368-404.

13 FAO. Calorie Requirements. Report of the Second Committee on Calorie Requirements. Nutritional Studies No. 15. Rome: Food and Agriculture Organization, 1957.

14 Roth PR. Portable respiration apparatus for clinical use. Boston Medical Surgery Journal 1922; 186: 457.

15 Boothby WM, Berkson J, Dunn HL. Studies of the energy metabolism of normal individuals: a standard for basal metabolism, with a nomogram for clinical application. American Journal of Physiology 1936; 116: 468-84.

16 Durnin JVGA. Basal Metabolic Rate in Man. Working paper submitted to the Joint FAO/WHO/UNU Expert Consultation on Energy and Protein Requirements. Rome: Food and Agriculture Organization, 1981

17 Krogh A. Respiratory Exchange of Animals and Man. New York: Longmans, 1916.

18 Benedict FG. Portable respiration apparatus for clinical use. Boston Medical Surgery Journal 1918; 178: 667.

19 Lewis RC, Iliff A, Duval AM. Further consideration of the effect of altitude on basal metabolism. The Journal of Nutrition 1943; 26: 175-85.

20 Lewis RC, Iliff A, Duval AM. The comparative accuracy of the closed circuit bedside method and the open circuit chamber procedure for the determination of basal metabolism. Journal of Laboratory Clinical Medicine 1943; 28 $1238-45$. 
21 Lewis RC, Duval AM, Iliff A. Standards for the basal metabolism of children from 2 to 15 years of age, inclusive. Journal of Pediatrics 1943; 23: 1-18.

22 Willard HN, Wolf GA Jr. A source of error in the determination of basal metabolism by the closed-circuit technique. Annual International Medicine 1951; 34: $148-62$.

23 Segal KR. Comparison of indirect calorimetric measurement of resting energy expenditure with a ventilated hood, face mask, and mouthpiece. American Journal of Clinical Nutrition 1987; 45: 1420-3.

24 Shetty PS, Soares MJ, Sheela ML. Basal Metabolic Rates of South Indian Males. Bangalore: Food and Agriculture Organization, 1986.

25 Soares MJ, Sheela ML, Kurpad AV, Kulkarni RN, Shetty PS. The influence of different methods on basal metabolic rate measurements in human subjects. American Journal of Clinical Nutrition 1989; 50: 731-6.

26 Consolazio CF, Johnson RE, Pecora LJ. Physiological Measurements of Metabolic Function in Man. New York: McGraw-Hill, 1963.

27 Clark HD, Hoffer LF. Reappraisal of the resting metabolic rate of normal young men. American Journal of Clinical Nutrition 1991; 53: 21-6.

28 Fowler WS, Blackburn CM, Helmholz HF Jr. Determination of basal rate of oxygen consumption by open and closedcircuit methods. Journal of Clinical Endocrinological Metabolism 1957; 17: 786-96.

29 Schofield WN, Schofield C, James WPT. Basal metabolic rate - review and prediction, together with an annotated bibliography of source material. Human Nutrition Clinical Nutrition 1985; 39C: 5-96.

30 DuBois D, DuBois EF. The measurements of the surface area of man. Archives of Internal Medicine 1915; 15: 868-75.

31 Daly JM, Heymsfield SB, Head CA, Harvey LP, Nixon DW, Katzeff H, Grossman GD. Human energy requirements: over estimation by widely used prediction equation. The American Journal of Clinical Nutrition 1985; 42: 1170-4.

32 Alpers PH, Stevenson WF, Bier DM. Manual of Nutritional Therapeutics. Philadelphia: Lippincott Williams and Wilkins, 1995.

33 Boothby WM, Sandiford I. A comparison of the DuBois and the Harris and Benedict normal standards for the estimation of basal metabolic rate. Journal of Biological Chemistry 1922; 54: 767-81.

34 Boothby WM, Sandiford I. Summary of the basal metabolic data on 8614 subjects with special reference to the normal standards for the estimation of the basal metabolic rate. Journal of Biological Chemistry 1922; 54: 783-803.

35 Quenouille MH, Boyne AW, Fisher WB, Leitch I. Statistical Studies of Recorded Energy Expenditure of Man. Basal Metabolism Related to Sex, Stature, Age, Climate, and Race. Commonwealth Bureau of Animal Nutrition. Technical Communication No. 17. Aberdeen: Commonwealth Agricultural Bureau, 1951.

36 de Almeida AO. L'émission de chaleur. Le métabolisme basal et le métabolisme mimimum de l'homme noir tropical. Journal de Physiologie et Pathologie Géneral 1921; 18: 958-64.

37 Henry CJK, Rees DG. New predictive equations for the estimation of basal metabolic rate in tropical peoples. European Journal of Clinical Nutrition 1991; 45: 177-85.

38 de Boer JO, van Es AJH, Voorrips LE, Blockstra F, Vogt JE. Energy metabolism and requirements in different ethnic groups. European Journal Clinical Nutrition 1988; 42 : 983-97.

39 Arciero PJ, Goran MI, Gardner AM, Ades PA, Tyzbir RS, Poehlman ET. A practical equation to predict resting metabolic rate in older females. Journal of American Geriatric Society 1993; 41: 389-95.
40 Piers LS, Shetty PS. Basal metabolic rates of Indian women. European Journal of Clinical Nutrition 1993; 47: 586-91.

41 Hayter JE, Henry CJK. A re-examination of basal metabolic rate predictive equations: the importance of geographic origin of subjects in sample selection. European Journal of Clinical Nutrition 1994; 48: 702-7.

42 Valencia ME, Moya SY, McNeill G, Haggarty P. Basal metabolic rate and body fatness of adult men in northern Mexico. European Journal Clinical Nutrition 1994; 48 : 205-11.

43 Wong WW, Butte NF, Hergenroeder AC, Hill RB, Stuff JE, Smith EO. Are basal metabolic rate prediction equations appropriate for female children and adolescents? Journal of Applied Physiology 1996; 81: 2407-14.

44 Soares MJ, Francis DG, Shetty PS. Predictive equations for basal metabolic rates of Indian males. European Journal of Clinical Nutrition 1993; 47: 389-94.

45 Cruz CM, daSilva AF, dos Anjos LA. A taxa metabica basal e superestimade pelas equa co es preditivas em universitaras do Rio de Janeiro, Brasil. Archivio Latino americano Nutricion 1999; 49: 232-7.

46 Dietz WH, Bandini LG, Schoeller DA. Estimates of metabolic rate in obese and non-obese adolescents. Journal of Pediatrics 1991; 118: 140-9.

47 Cunningham JJ. A reanalysis of the factors influencing basal metabolic rate in normal adults. American Journal of Clinical Nutrition 1980; 33: 2372-3374.

48 Cunningham JJ. Body composition as a determinant of energy expenditure: a synthetic review and a proposed general prediction equation. American Journal of Clinical Nutrition 1991; 54: 963-9.

49 Hayter J, Henry CJK. Basal metabolic rate in human subjects migrating between tropical and temperate regions - a longitudinal study and review of previous work. European Journal of Clinical Nutrition 1993; 47: 724-34.

50 Ho Z-C, Zi HM, Bo L, Ping H. Energy expenditure of pre school children in a subtropical area. World Reviews in Nutrition Dietetics 1988; 57: 75-94.

51 Min Q, Ho Z-C. The basal metabolism rate of adolescent girls in the sub-tropical areas of China. Acta Nutrimenta Sinica 1991; 13: 252-8.

52 Spurr GB, Reina JC, Hoffmann RG. Basal metabolic rate of Colombian children 2-16 years of age: ethnicity and nutritional status. American Journal of Clinical Nutrition 1992; 56: 623-9.

53 Torun B, Davies PSW, Livingstone MBE, Paolisso M, Sackett R, Spurr GB. Energy requirements and dietary energy recommendations for children and adolescents 1 to 18 years old. European Journal of Clinical Nutrition 1996; 50(Suppl. 1): $\mathrm{S} 37-\mathrm{S} 81$.

54 Livingstone MBE, Coward WA, Prentice AM, Davies PSW, Strain JJ, McKenna PG, Mahoney CA, White JA, Stewart CM, Kerr MJJ. Daily energy expenditure in free living children: comparison of heart-rate monitoring with the doubly labelled water $\left({ }^{2} \mathrm{H}_{2}^{18} \mathrm{O}\right)$ method. American Journal of Clinical Nutrition 1992; 56: 343-52.

55 Bandini LG, Schoeller DA, Dietz WH Jr. Energy expenditure in obese and non-obese adolescents. Pediatric Research 1990; 27: 198-203.

56 Case KO, Brahler CJ, Heiss C. Resting energy expenditures in Asian women measured by indirect calorimetry are lower than expenditures calculated from prediction equations. Journal of American Dietetic Association 1997; 97: 1288-92.

57 Leung R, Woo J, Chan D, Tang N. Validation of prediction equations for basal metabolic rate in Chinese subjects. European Journal of Clinical Nutrition 2000; 54: 551-4.

58 Piers LS, Diffey B, Soares MJ, Frandsen SL, McCormack LM, Lutschini MJ, O'Dea K. The validity of predicting the basal metabolic rate of young Australian men and women. European Journal of Clinical Nutrition 1997; 51: 333-7. 
59 Ferro-Luzzi A, Petracchi C, Kuriyan R, Kurpad AV. Basal metabolism of weight-stable chronically undernourished men and women: lack of metabolic adaptation and ethnic differences. American Journal of Clinical Nutrition 1997; 66: $1086-93$.

60 Yamauchi T, Ohtsuka R. Basal metabolic rate and energy costs at rest and during exercise in rural- and urban-dwelling Papua New Guinea Highlanders. European Journal of Clinical Nutrition 2000; 54: 494-9.

61 Norgan NG. Population differences in body composition in relation to the Body Mass Index. European Journal of Clinical Nutrition 1994; 48(Suppl. 3): S10-S27.

62 Shetty PS, Henry CJK, Black AE, Prentice AM. Energy requirements of adults: an update on basal metabolic rates (BMRs) and physical activity levels (PALs). European Journal of Clinical Nutrition 1996; 50(Suppl. 1): S11-S23.

63 Hayter J, Henry CJK. Basal metabolic rate in human subjects migrating between tropical and temperate regions - a longitudinal study and review of previous work. European Journal of Clinical Nutrition 1993; 47: 724-34.

64 Poehlman ET, Melby CL, Badylak SF. Resting metabolic rate and post-prandial thermogenesis in highly trained and untrained males. American Journal of Clinical Nutrition 1988; 47: 793-8.

65 Robertson JD, Reid DD. Standards for the basal metabolism of normal people in Britain. The Lancet 1952; 1: 940-9.

66 Benedict FG, Garven HSD. The basal metabolism of male Chinese in Manchuria. Chinese Journal of Physiology 1936; 10: $141-8$.

67 Benedict FG, Meyer MH. The basal metabolism of Americanborn Chinese girls. Chinese Journal of Physiology 1933; 7 : 45-60.

68 Benedict FG, Miles WR, Roth P, Monmouth Smith H. Human Vitality and Efficiency Under Prolonged Restricted Diet. Washington: Carnegie Institution of Washington, 1919, 280.

69 Benedict FG, Talbot FB. The Gaseous Metabolism of Infants Washington: Carnegie Institution of Washington, 1914, 201.

70 Benedict FG. Age and basal metabolism of adults. Journal of Biological Chemistry 1928; 80: 650-64.

71 Benedict FG. Basal metabolism data on normal men and women (series II) with some considerations on the use of prediction standards. Journal of Biological Chemistry 1928; 8: $607-20$

72 Benedict FG. Factors affecting basal metabolism. Journal of Biological Chemistry 1915; 20: 263-99.

73 Benedict FG. Metabolism and Growth from Birth to Puberty. Washington: Carnegie Institution of Washington, 1921, 302.

74 Benedict FG. Old age and basal metabolism. New England Journal of Medicine 1935; 212: 1111-23.

75 Benedict FG. The basal metabolism of girls 12 to 17 years of age. Proceedings of the National Academy of Science 1921; VII: $10-13$.

76 Lewis RC, Kinsman GM, Iliff A. The basal metabolism of normal boys and girls from two to twelve years old, inclusive. American Journal of Diseases in Childhood 1937; 53: $348-428$.
77 Lewis WH. Changes with age in the basal metabolic rate in adult men. American Journal of Physiology 1934; 12: 502-17.

78 Mason ED, Benedict FG. The basal metabolism of South Indian Women. Independent Journal of Medical Research 1931; 19: 75-98.

79 Mason ED, Benedict FG. The effect of sleep on human basal metabolism, with particular reference to South Indian women. American Journal of Physiology 1934; 108: 377-83.

80 Mason ED, Jacob M. Variations in basal metabolic rate: responses to changes between tropical and temperate climates. Human Biology 1972; 44: 141-72.

81 Mason ED. The basal metabolism of European women in South India and the effect of change of climate on European and South Indian Women. Journal of Nutrition 1934; 8 : $695-713$.

82 Nakagawa I. Growth and basal metabolism. Basal metabolism of preschool children. American Journal of Diseases in Childhood 1934; 47: 963-9.

83 Nakagawa I. Growth and basal metabolism. Basal metabolism of elementary school children. American Journal of Diseases in Childhood 1934; 48: 34-8.

84 Nakagawa I. Growth and basal metabolism. Changes in the basal metabolism of children during a year. American Journal of Diseases in Childhood 1935; 49: 1232-9.

85 Nakagawa I. Growth and basal metabolism. Basal metabolism of high school children. American Journal of Diseases in Childhood 1937; 51: 985-9.

86 Wardlaw HSH, Davies HW, Joseph MR. Energy metabolism and insensible perspiration of Australian Aborigines Australian Journal of Experimental Biology 1934; 12: 63-73.

87 Wardlaw HSH, Horsley CH. The basal metabolism of some Australian Aborigines. Australian Journal of Experimental Biology 1928; 5: 263-72.

88 Wardlaw HSH, Lawrence WJ. Further observations on the basal metabolism of Australian Aborigines. Australian Journal of Experimental Biology 1932; 10: 157-65.

89 Wang CC, Hawks JE. Basal metabolism of twenty-one Chinese children reared or born and reared in the United States. American Journal of Diseases in Childhood 1932; 44: 69-80

90 Wang CC, Kaucher M, Wing M. Metabolism of adolescent girls. Basal metabolism and energy exchange. American Journal of Diseases in Childhood 1936; 51: 801-15.

91 Wang CC, Kern R, Frank M, Hays BB. Metabolism of undernourished children. Basal metabolism. American Journal of Diseases in Childhood 1926; 32: 350-9.

92 Wang CC. Basal metabolism and preformed total creatinine in urine of seventy children. American Journal of Diseases in Childhood 1939; 57: 838-50.

93 Wang CC. Basal metabolism of American-born Chinese girls and of American girls of the same age. American Journal of Diseases in Childhood 1934; 48: 1041.

94 Holland B, Welch AA, Unwin ID, Buss DH, Paul AA, Southgate DAT. McCance and Widdowson's the Composition of Foods, 5th edn. Cambridge: Royal Society of Chemistry, 1991. 